\title{
Dönemlendirme Çalışmaları ve Osmanlı-Türk Müziği Tarihyazımı: Bir Bilanço Denemesi
}

\author{
Hasan Baran Firat ${ }^{*}$
}

\begin{abstract}
Özet
Geniş bir zaman dilimi üzerine yoğunlaşan tarih çalışmaları için dönemlendirme neredeyse kaçınılmaz bir tartışma başlığı niteliğindedir. Buna rağmen dönemlendirmeyi tarihyazımında başlı başına bir yöntem olarak ele alan inceleme sayısı oldukça kısıtlıdır. Bu nedenle çoğu zaman, uzun zaman dilimleri üzerinde çalışan araştırmacılar kendi dönemlendirme teorilerini geliştirmek zorunda kalmıştır. Bu çerçeveden Osmanlı-Türk müziğine bakıldığında ise dönemlendirmenin yine oldukça tartışmalı bir başlık olduğu kolaylıkla söylenebilir. Bu çalışmada dönemlendirmenin bu tartışmalı yönleri gerek tarihyazımı gerekse de Osmanlı-Türk müziği ve kültürü çalışmaları üzerinde ele alınmıştır. illk bölümde araştırmanın genel kapsamını çizdikten sonra, ikinci bölümde tarih, mimari ve müzik alanlarında bugüne kadar ortaya atılmış dönemlendirme önerilerinin bir bilançosu çıarılarak, Osmanlı-Türk müziğinde dönemlendirmenin önemine dikkat çekilmeye çalışılmıştır. Öne çıkan bazı dönemlendirme başlıkları ile çokça tartışlan kaynak verisinin genişletilmesi fenomeni üzerinde durulması amaçlanmıştır. Başta Fernand Braudel ve Reinhart Koselleck olmak üzere tarihsel zaman teorisi üzerinde çalışan bazı araştırmacıların yaklaşımlarını referans alarak Osmanlı-Türk müziğinde dönemlendirmeye nasıl yaklaşılabileceği üzerine bir yol haritası çıkarılmaya çalışılmıştır. Makale Osmanlı-Türk müziği ve kültür tarihi dönemlendirmesi üzerine öncelikli bazı tartışma konularına dikkat çektikten sonra, bu tartışmaların tarihsel icra mefhumu ile olan ilişkisine değinerek sonlanmaktadır.
\end{abstract}

Anahtar kelimeler: dönemlendirme, tarihsel zaman, Osmanlı-Türk müziği, üslup

Periodization and Ottoman-Turkish Music Historiography: A Review

\begin{abstract}
Periodization is a fundamental subject in historiography, and it is inevitable to call upon it in a study on the past. Nevertheless, it is difficult to come across research on general aspects of periodization. Therefore, scholars studying long time periods in the past have had to develop their own periodization theories. When we look at the field of Ottoman-Turkish music from this perspective, surely it can be said that periodization is a highly questionable topic. This article aims to discuss periodization in terms of both historiography and OttomanTurkish culture and music studies. After explaining the scope of the research in the first part, the second part of the article focuses on a list of different periodization suggestions in history, architecture, and music in somewhat chronological order and tries to emphasize the importance of the issue of periodization in Ottoman-Turkish music studies. In this way, the article aims to reconsider the necessity of broadening historical sources for Ottoman-Turkish music and reflects on some of the predominant periodization debates. The study is based on a structuralist view of periodization considers the works of scholars such as Fernand Braudel and Reinhart Koselleck, who worked on historical time theory. Finally, the article concludes by referring to the predominant debates on periodization in Ottoman-Turkish music and cultural history and to the relationship of these debates to historically informed performance.
\end{abstract}

Keywords: periodization, historical time, Ottoman-Turkish music, stylistic change

\footnotetext{
* Università degli Studi della Campania “Luigi Vanvitelli," hbaranf@gmail.com

Bu makaleyi sonlandırırken birçok ismin kıymetli fikir ver önerilerini aldım. Makalenin önceki versiyonlarını okuyarak kıymetli görüşlerini paylaşan Alper Maral, Ahmet Ersoy, Zeynep Yıldız Abbasoğlu ve Mehmet Uğur Ekinci'ye teşekkür ederim.
} 
Yaşamımızın bu akıntısı altında, onun içinde, ters yönde akan başka bir akıntı var; burada dünden yarına gidiyoruz, orada yarından düne gidiliyor. Bir anda hem örülüyor, hem çözülüyor. Ve arada bir öteki dünyadan, bizim dünyamızın içinden esintiler, buharlar ve hatta gizemli gürültüler bize kadar geliyor. Tarihin derinlikleri bir karş1-tarihtir, izlediği tarihin ters yönünde bir süreç. Yeraltı ırmağı denizden kaynağa gider.

Miguel de Unamuno ${ }^{1}$

Bu makalede dönem kavramı üzerinden son yıllardaki Osmanlı-Türk müziği çalışmalarının genel bir değerlendirmesini sunmaya çalışıyorum. Yeni bir dönemlendirme önermek yerine, başta tarih ve mimarlık alanlarından paralel okumalar ile kaynak verisinin nasıl genişletilebileceği, üslup/stil temelli kapsayıc bir dönemlendirme önerisi geliştirmenin yol ve imkânları üzerine yoğunlaşıyorum. Dönem ve yapısalcılık üzerine teorik bazı tartışmalara da dikkat çeken çalışma, sanat tarihi alanında gelenekselleşmiş, indirgemeci dönemlendirmelerin Osmanlı-Türk müziği ve sanatındaki karşlıkları üzerine bir okuma niteliğindedir.

Osmanlı-Türk müziği son yıllarda artış gösteren düzeyde bir akademik ilgiye muhatap olmaktadır. Bu artış yeni birçok başlığın açılmasına imkân vermekle beraber ortak kanaatin tesis edilemediği hasıraltı edilen bazı konuların da yeniden ele alınmasına ortam sağlıyor. $\mathrm{Bu}$ çalışmada değineceğim dönem kavramı da özellikle Osmanlı-Türk müziği tarihi yazımında sıkça dillendirilen, yazılı kaynakların yetersizliği meselesi ile oldukça tartışmalı hale gelmiştir. ${ }^{2}$ Buna rağmen en erken tarihli değerlendirmeler ile yaklaşık 500 yıllık bir geçmişe dayandırılan Osmanlı-Türk müziğini, ${ }^{3}$ yekpare bir bütün olarak ele almanın imkânsızlığı, özellikle son 50 yılda yazılı kaynaklar üzerinde gerçekleştirilen muhtelif araştırmalarla da ortaya konmuştur. ${ }^{4}$ Ali Ufkî Bey'in Mecmua-i Sâz ü Söz'ü başta olmak üzere musiki yazmaları, Kantemiroğlu'nun Edvârı, Nâyî Mustafa Kevserî Efendi'nin Mecmuası, içinden sadece birkaç notanın neşredildiği Nâyî Osman Dede'nin Defteri gibi yazılı kaynakların nitelikli edisyon ve yayınlarla tekrar gündeme getirilmeleri konuyu yeniden ele almak için uygun bir zemin hazırlamıştır. ${ }^{5} \mathrm{Bu}$ yazmalar, içerdikleri nota derlemeleri ile dönemlerinin müziği hakkında kayda değer bilgiler sunabilen en ciddi kaynaklardır. Hafız Post'un mecmuasi ${ }^{6}$ başta olmak üzere güfte mecmuaları, ${ }^{7}$ Şeyhülislam Es'ad Efendi'nin Atrabü'l Âsâr' ${ }^{8}$ gibi yazmaları da bir alt başlıkta bunlara eklemek mümkün. Bu veri kaynağının bir başlangıç noktası sunabileceğini düşünmek mümkünse de tüm bu kaynakları bir arada ele alabilecek çalışmalar için belli bir süreye daha ihtiyaç var gibi görünüyor. Bu çerçevede sayıları hızla artan, çokça kıymetli çalışmayı göz önünde bulundurarak bir artış/iyileşme olduğu söylenebilir; fakat mevcut pratikler halen bazı kapıların aralanmasına; çerçevelerin zorlanmasına mâni olmaya devam etmektedir. Bugüne kadar alana hor

1 Miguel de Unamuno, Sis (İstanbul: İș Bankası Kültür Yayınları, 2016), 38.

2 En başta Cem Behar'ın, dönem analizinin imkânsızlığı kanaatini birçok vesile ile ifade etmekle beraber, konu ile ilgili çeșitli bașlıklar üzerine pek çok değerlendirmesi mevcuttur. Bkz. Cem Behar, Şeyhülislâmın Müziği - 18. Yüzyılda Osmanlı/Türk müziği ve Şeyhülislâm Es'ad Efendi'nin Atrâbüll Âsâr (İstanbul: Yapı Kredi Yayınları, 2010), 22.

3 Son dönem çalışmalarında özgün bir Osmanlı-Türk müziği geleneği genel bir kabul olarak on altıncı ya da on yedinci yüzyıldan başlatılır olmuştur. Owen Wright, Words Without Songs: A Musicological Study of an Early Ottoman Anthology and its Precursors (Londra: SOAS Musicology Series, 1992); Behar, Şeyhülislâmın Müziği.

4 Tam tersi bir kanaatin uzun yillar boyunca hâkim olmasına, modern Türk müzikolojisinin kurucu figürü olarak nitelendirilebilecek Rauf Yekta’nın katkısı büyüktür. On yedinci yüzyılda Kantemiroğlu’nun gösterip Rauf Yekta'nın gösteremediği müzikolojik yaklaşımın eleştirisi için bkz. Walter Feldman, "The Musical 'Renaissance' of Late Seventeenth Century Ottoman Turkey: Reflections on the Musical Materials of Ali Ufkî Bey (ca. 1610-1675), Hâfız Post (d. 1694) and the 'Marâghî' Repertoire," Writing the History of "Ottoman Music," der. Martin Greve, çev. Efkan Uğuz, Martin Greve ve Onur Nobrega (Würzburg: Ergon-Verlag, 2015), 129-130.

5 Bu edisyonlardan bazıları için bkz. Cem Behar, Saklı Mecmua: Ali Ufkînnin Bibliotheque Nationale de France'daki [Turc 292] Yazmast (İstanbul: Yapı Kredi Yayınları, 2008); Judith I. Haug, Ottoman and European Music in 'Alī Ufukī’s Compendium, MS Turc 292: Analysis, Interpretation, Cultural Context (Münster: WWU Münster, 2019); M. Hakan Cevher, "Ali Ufki ve Haza Mecmua-i Saz ü Söz. Transkripsiyon ve İnceleme" (doktora tezi, Ege Üniversitesi, 1995); Ali Ufki, Mecmua-i Saz ü Söz, haz. Şükrü Elçin (Ankara: T.C. Kültür Bakanlığı, 2ooo); Nilgün Doğrusöz, "Nâyî Osman Dede’nin Müzik Yazısına Dair Birkaç Belge” Musıkişinas 8 (2006): 47-66; Kantemiroğlu, Kantemiroğlu Edvârı, çev. Yalçın Tura, c. I, II (İstanbul: Yapı Kredi Yayınları, 20o1); Owen Wright, Demetrius Cantemir: The Collection of Notations (Londra: SOAS Musicology Series, 1992); Eugenia Popescu-Judetz, Tanburi Küçük Artin: A Musical Treatise of the Eighteenth Century (İstanbul: Pan Yayıncılık, 2002); Kevserî Mecmuast, çev. Bülent Aksoy (İstanbul: Pan Yayıncllık, 1998); Mehmet Uğur Ekinci, Kevserî Mecmuast - 18. Yüzyll Saz Müziği Külliyatı (İstanbul: Pan Yayıncılık, 2016). Bizans notası arşivlerinin din-dışı müzik için kaynak olarak kullanılabilirliğini ele alan ilgi çekici bir çalışma için bkz. Kyriakos Kalaitzides, Post-Byzantine Music Manuscripts as a Source for Oriental Secular Music (15th to Early 19th Century), çev. Dimitri Koubaroulis (Würzburg: Ergon-Verlag, 2012). Ayrıca Münster Üniversitesi bünyesinde gerçekleştirilen, henüz bir yayını olmamasına rağmen on dokuzuncu yüzyıl Hamparsum notalarının transkripsiyonu ile başlayacak on dokuzuncu yüzyıl müziğinin rekonstrüksiyonu gibi nihai bir hedefi olan geniş kapsamlı bir proje için bkz. Corpus Musicae Ottomanicae https://www.unimuenster.de/CMO-Edition/tr/cmo/beschreibung.html.

6 Bkz. Nilgün Doğrusöz, "Hâfız Post Güfte Mecmuası (Türkçe Güfteler)" (yüksek lisans tezi, İstanbul Teknik Üniversitesi, 1993).

7 İstanbul Üniversitesi Nadir Eserler Kütüphanesi'nde bulunan çok sayıdaki güfte mecmusı kataloğu için bkz. Harun Korkmaz, The Catalog of Music Manuscripts in Istanbul University Library (Cambridge: Harvard University, 2015).

8 Behar, Şeyhülislâmın Müziği. 
görme-kutsama karşıtlı̆̆ında gelişen bir retoriğin hâkim olduğunu söylemek yanlış olmaz. İki kutupta da hamaset ve yüzeyselliğin hüküm sürdüğu bu retorik sonucu oluşan güvensiz bilgi ortamı ve yazılı kaynaklar ekseninde yavaş yavaş genişleyen literatür, belgeye (nota, vb.) dayalı Rankeci, materyalist bir tarih-müzikoloji anlayısının alana hâkim olması sonucunu doğurmuştur. Müzikolojiyi besleyen siyasî/toplumsal tarih, sanat tarihi, antropoloji, sosyoloji gibi disiplinlerin her birinin katkısı yerine tarih merkeze konumlandırılarak eldeki bilgi ve belgelerin yorumlanması önünde bir çeşit metodolojik ve hatta psikolojik engel oluşmasına neden olmuştur. Belgeye dayalı tarihin dışında kalan müzikoloji çalışmalarının (sistematik müzikoloji, etnomüzikoloji, vb.) bir tür itibarsızlaştırılma ekseninde, deyim yerindeyse dışlanmasına sebep olmuş, bu da alanın daralması sonucunu doğurmuştur. Bu olgu sosyal bilimlerin doğasındaki işleyişe, özellikle de Il. Dünya Savaşı sonrasındaki dönüşüme ters düşen bir durumu yansıtmaktadır. ${ }^{9}$ Bu çelişki, özellikle Türkiye'de işleyen müzikoloji disiplinini çağdaş sosyal bilimlerin hep bir adım gerisinde kalmasına neden olmuştur. Kaldı ki, bu tür bir müzikolojinin dayanak aldığı tarih disiplinin Türkiye seyri de benzer bir çizgide gelişmiştir. Avrupa ve Kuzey Amerika merkezli dünya ile entegre gerçekleştirilen akademik çalışmalar bir tarafa bırakılacak olursa, müziğin de tarih alanında çokça tartışılan "defteroloji” ile çepeçevre kuşatılmış olduğunu teslim etmek gerekir. ${ }^{10}$

\section{Dönemlendirme Şart Mıdır?}

Yukarıda vurgulanan belgeye dayalı tarihyazımı ilişkisi, müzik tarihi söz konusu olduğunda daha da daralan bir örneklemle, nota ve tamamlayıcı yönergelerden oluşan (edvar, vb.) bir malzemeyle sınırlanacaktır. Osmanlı-Türk müziği geleneğinde nota yazımının kullanılmaması bu bağlamda ilk akla gelecek sorun alanını ifşa eder. Meşk usulü, ilk akla geldiği şekli ile birçok eserin günümüze ulaşamamasından daha kritik kayıplar doğurmuştur. Hiçbir dönemde yaygınlaşmayan nota yazımı girişimleri sonucu elimize ulaşan hatırı sayılır sayıdaki eserin notası da bu sorunu çözmeye yeterli olamamıştır. Meşk zinciri içinde talebeye aktarılan her eser, hocanın üslubundaki farklılıklarla beraber aktarılmış, geleneğin doğası gereği beste, eser — bir "açık yapıt" örneği olarak-her seferinde tekrar yorumlanmıştır. ${ }^{11}$ Bu tekrar yorum hali hoca-talebe arasında büyük değişimleri ifade etmese bile geniş zaman dilimlerine bakıldığında daha ciddi üslup farklılıklarından bahsi zorunlu kılmıştır. Bugün Itrî̀ye (ö. 1712) atfedilen bir eser ile Tanburi Cemil Bey'e (1871-1916) ait bir eserin aynı repertuvar içinde yer alabiliyor olması, çokça yorumlandığı şekliyle değişimin yokluğunu değil, geleneğin (meşk usulünün) dönüştürücü ve birleştirici etkisini destekler niteliktedir.

Meşk zinciriyle-tarihin eleğinden geçerek-günümüze ulaşan çokça eser geleneğin fotoğrafının çekilebildiği ilk anın, eserlerin notaya alındığı son dönemin üslup, zevk ve estetik anlayışlarını sergilemektedir. Bu durum mevcut nota külliyatı üzerinden bir üslup ve buna mukabil bir dönem analizi yapılmasını sağlam bir temelden mahrum bırakmıştır. ${ }^{12}$ Örneğin, Dede Efendi’nin hayatı ve eserleri üzerine yaptığı kronoloji denemesinde Cem Behar şunları dillendirmeden geçemez; "...eserlerinin anlamlı, sağlam ve ikna edici bir üslûp analizini yapmaya çalışmak, yine Ahmet Hamdi Tanpınar'ın ifadesiyle, sadece 'imkânsızın peşinde bir çırpınış’tan ibaret kalmaya mahkûm olabilir."'’3 Ortaya konulabilecek bir-iki istisna haricinde, eldeki veri gerçekten de bir bestekâr özelinde üslup farklılıklarından bahse imkân tanımamaktadır. Bununla birlikte kayıt teknolojisinin geliştiği son yüzyıl içinde gözlemlenebilen üslup değişiminin dahi tasnif edilemediği, tek bir Osmanlı-Türk müziği tanımının muhatabına göre binlerce farklı anlamı karşıladığı da pratik bir gerçekliktir. Sınırlar çizmeden, içini doldurmadan, çok genellemeci bir yaklaşımla bile dillendirebileceğim, on beşinci

\footnotetext{
9 Immanuel Wallerstein, Yeni Bir Sosyal Bilim İçin (İstanbul: İmge Kitabevi, 2003). Ayrıca bkz. Gulbenkian Komisyonu, Gulbenkian Komisyonu Sosyal Bilimleri Açın, çev. Şirin Tekeli (İstanbul: Metis Yayınları, 2016).

10 Oktay Özel, Dün Sancıst, Türkiye'de Geçmiş Algısı ve Akademik Tarihçilik (İstanbul: Kitabevi Yayınevi, 2009); Heath W. Lowry, Defterology Revisited: Studies on 15th and 16th Century Ottoman Society (İstanbul: The ISIS Press, 2008). Benzer biçimde Osmanl1-Türk müziği alanına bakıldığında da güfte mecmuaları ve edvârların, "defteroloji” eleştirisine konu olan anlayışla, hocadan öğrenciye verilen bir ödev şeklinde çalışlageldiği görülmektedir.

11 Umberto Eco, Açı Yapıt, çev. Yakup Şahan (İstanbul: Kabalcı Yayıncılık, 1992); Cem Behar, Aşk Olmayınca Meşk Olmaz: Geleneksel Osmanl/Türk Musıkisinde Öğretim ve İntikal (İstanbul: Yapı Kredi Yayınları, 2016).

12 Yalçın Tura, Türk Musikisinin Meseleleri (İstanbul: Pan Yayıncılık, 1998), 38.

13 Cem Behar, Osmanlı/Türk Mustkisinin Kısa Tarihi (İstanbul: Yap1 Kredi Yayınlar1, 2015), 109.
} 
148 yüzyıl ve öncesi müziği, on altı ve on yedinci yüzyıl müziği ve on dokuzuncu yüzyıl müziği ile Cumhuriyet dönemindeki müziğin, genel üslup farklılıkları veya kendine has sorunları henüz hakkınca analiz edilebilmiş değildir. ${ }^{14}$ Klasik tavır, klasik koro, klasik üçlü, klasik beşli gibi kavramların alanda karşılık geldiği icra pratiklerinin, "klasik" kavramının sözlük karşılığından tamamen bağımsız ifadesi, üsluba ve dönemlere dair kafa karışıklıklarının açık örneğidir. Bugün Türkiye toplumunun çoğu alanda içselleştirdiği modern yaklaşımlar, kendi müziğinin tarihi söz konusu olduğunda yerini modern öncesi ${ }^{15}$ bir kavrayışa bırakmaktadır. Gelenek bir tarih perspektifinden yoksun, sadece çağdaş boyutu ve üslubu ile ele alınmaktadir.

'On yedinci yüzyıl İstanbul sokak, kahvehane veya meclislerinde ne gibi sesler kulakları doldurmaktaydı'; 'tanburun tınısı ya da çalış üslubu bugünkü ile aynı mıydı'; 'bugün ney icrası merkezinde şekillenen "klasik üslubun" kökenini ne derece geriye götürebiliyoruz' gibi arka arkaya sıralanabilecek birçok temel soru Osmanlı-Türk müziğinin henüz öncelikli meseleleri olarak ele alınamamışırı. Elbette ki zihinlerimiz, tarihi ya da modern herhangi bir olguyu algılama/yorumlama noktasında çağdaş yaklaşımların hegemonyası altındadır. Ancak çağdaş olgular bir tarafa, tarihi olana gösterilecek yaklaşım, zamanın değişen ve dönüştüren etkisini göz önünde bulundurmak zorundadır. Zamanın çözümlenebilmesi, ilişkilerin uygun bağlamlarda değerlendirilebilmesi ile mümkün olabilir. ${ }^{16} \mathrm{Bu}$ ilişkilerin günümüz bakış açısıyla değerlendirilerek bir hikâyeye dönüştürülmesi ise ilk örneğini Giorgio Vasari'nin (1511-1574) verdiği kabul edilen, asıl olarak on dokuzuncu yüzyılda bir disipline dönüşen sanat tarihi çalışmalarının öncelikli işi olmuştur. Orta Çağ’dan modernliğe doğru akan birbiri ardına sıralanmış dönemlerden oluşan, homojen çizgisel tarih anlatısı tam da bu hikâyelerin ana hattını oluşturur. Bir tarafta Vasari, Gombrich ve Greenberg gibi yazarlar sanat tarih anlatılarını eser ya da sanatçının içsel değişim ve gelişimi ile ilişkilendirirken; Hegelci ve Marksist sanat tarihi anlatısı toplumsal ve daha geniş kültürel olaylar üzerinde kurulmuştur. Ancak materyalist ve idealist olarak özetleyebileceğimiz iki eğilimde de nedensellik üzerinde yükselen tek ve lineer tarih anlatısı son yıllarda çokça sorgulanmıştır. ${ }^{17} \mathrm{Bu}$ sorgulamaların yarattığı eleştirel pozisyonu korumakla beraber Osmanlı-Türk müziğinin kendine has koşulları, bugüne kadar tatmin edici bir tarih anlatısının ortaya koyulamaması gibi etkenler, dönemlendirmeden bahis açarken belli tercih ve yönelimlerde bulunmamızı zorunlu kılıyor. Post-yapısalcı bir eğilimin ürünü olan bu eleştiriler, Avrupa tarihi, sanatı ya da müziği anlatısı üzerinde yerleşik birçok kavramı yeniden değerlendirmeye açması ile sosyal bilimlere geniş bir çerçeve kazandırmıştır. Ancak ele aldığımız, Osmanlı-Türk müziği gibi üzerinde herhangi bir mutabakat sağlanmış yapının olmadığı bir alanda hâlâ yapısalcı yaklaşımlara ihtiyaç duymaktayız. Bir tarihyazım aracı olarak dahi çokça sorgulanan dönemlendirmeyi pek tabii nihai bir hedef olarak düşünmek değil, araçsal yönüyle ele almamız gerekir.

Her ne kadar kaynak yetersizliği problemi özellikle müzik alanında eldeki bilgi ve belgenin yetersiz olmasından çok çelişkili, değiştirilmiş ve nesnel açıdan güvensiz olmasından kaynaklansa da, eldeki veri kaynă̆ görece Vasari veya Gombrich’in denediği materyalist

14 Bu genellemeci ayrımla çizmek istediğim başı sonu belli bir dönemlendirme tablosundan ziyade bir bütün olarak kabul edilen bu "beş yüz yıllık" süreç içerisinde yaşanmış, en azından üç ya da dört farklı dönemin olduğuna dikkat çekmektir.

15 Burada müzik üzerinden kastedilen modern ve modern öncesi yaklașımlar, tarih algısının bu iki farklı dönemde nassl șekillendiğidir. Çok genel bir tanımlama ile erken modern dünyaya kadar tarih mit ve hikâyelerle kuşatılmış ve günceli anlamlandırmanın bir aracı iken, modern dünyada, kendi kapsamında ele alınması ve dışarıdan bir gözle değerlendirilmesi gereken bir bilimsel alan hüviyetini kazanmıştır. Modern düşüncenin bir ürünü olarak ele alınan Avrupa müziğindeki tarihsel icra kavramı da bu farklı kavrayışın ürünüdür. Bkz. John Butt, Playing with History, The Historical Approach to Musical Performance (Cambridge: Cambridge University Press, 2004).

16 Heinrich Wöfflin'in temelini attığı ve sanat eserlerini analizler yoluyla birbirleriyle ilişkilendirilmesi, dönemlendirilmesi, eserlerin tarihi bir kanıt kisvesiyle ele alındığı ve döneminin gerçek bir manada temsili olduğu kanaati son yıllarda birçok kez eleştirilmiştir. Postyapısalc1 etkilerin sürüklediği bu kanaat için bkz. Donald Preziosi, ed., The Art of Art History: A Critical Anthology (Oxford University Press, 2009), 7-11. Wöfllin'in Hegelci bir evrim çizgisinde sanat tarihine yön veren, eserlerin analizi için olusturduğu kavram çiftleri Osmanl1Türk müziği için kesinlikle halen ilham vericidir bkz. Heinrich Wölfflin, Sanat Tarihinin Temel Kavramları, çev. Hayrullah Örs (İstanbul: Remzi Kitabevi, 1973). Keza bu konuda öncü çalışmalara imza atan gerek Owen Wright gerekse de Walter Feldman'ın çalışmaları da aynı yaklaşım üzerinde şekillenmektedir: melodik yoğunluk artışı-azalışı, ritmik ağırlaşma-hızlanma örneklerinde olduğu gibi.

17 David Carrier, A World Art History and Its Objects (University Park: Pennsylvania State University Press, 2008), 30. Tarih disiplininde lineer dönemlendirme anlayıșının yeniden ele alındığı çalıșmalar için bașta Koselleck, Braudel ve Le Goff gibi tarihsel zaman teorisi üzerine çalışan yazarlar dikkate alınmalıdır bkz. Reinhart Koselleck, The Practice of Conceptual History: Timing History, Spacing Concepts, çev. Todd Presner et al. (Stanford University Press, 2002), özellikle 1-24; Kavramlar Tarihi: Politik ve Sosyal Dilin Semantiği ve Pragmatiği Üzerine Araştırmalar, der. Tanıl Bora, çev. Atilla Dirim (İstanbul: İletişim Yayınları, 20o6); Fernand Braudel, Maddi Uygarlk; Dünyanın Zamanı, çev. Mehmet Ali Kılıçbay (İstanbul: İmge Kitabevi, 2004); Tarih Üzerine Yazılar, çev. Mehmet Ali Kılıçbay (İstanbul: Doğu Batı Yayinlar1, 2016); Dietrich Gerhard, "Periodization in European History," The American Historical Review 61, s. 4 (1956): 900-913; Jacques Le Goff, Must We Divide History Into Periods?, çev. M.B. DeBevoise (New York: Columbia University Press, 2015). 
bir sanat tarihi anlatısını geliştirebilecek düzeyde değildir. Atrabül Âsâr benzeri biyografik kaynaklar veya Мecmua-i Sâz ü Söz gibi yeni nota külliyatları keşfedilmediği sürece, eldeki bilgi ve belgeleri ele almada yönlendirici ve birleştirici idealist eğilimlere bir nevi mecburuz. Şüphe götürmez gerçeklikleri ile arzıendam ederek uzunca bir geçmişi aydınlatacak tarihsel kaynakların keşfini beklemektense, bütüncül bir perspektifin ortaya konması son derece önemlidir. Post-yapısalcı birçok eleştiriyi dikkate alırken bir yapısalcılık dönemini yaşayamamış Osmanlı-Türk müzik tarihi için nihai noktada nesnel açıdan güvenilir bir tasnife ulaşılmasa bile yaygınlıkla kabul edilecek sübjektif bir tasnifin yaratacağı pratik faydaları göz önünde bulundurmak zorundayız. Hayden White'ın tarih ile kurgu arasındaki muğlaklığa yaptığı vurguya atfen $;^{18}$ kendi kurgusunu yazan Osmanl1-Türk müziğinin güncel birçok sorunun çözümüne, canlılığı üzerindeki tartışmaların son bulmasına imkân sağlayacağı umulur.

Bu çalışmada bugüne kadar bir şekilde ortaya atılan dönem önerilerinin bir bilançosunu çıararak, bu önerilerin tartışmalı taraflarına dikkat çekmeye çalışıorum. Tarih ve mimarlık alanlarında yaygınlık kazanmış dönemlendirmeleri tartışmaya dâhil ederek ve müzik dışında bir sanat ve kültür tarihi dönemlendirmesinin neresinde yer aldığımızı sergileyerek, paralel okumalara imkân sağlamayı amaçlıyorum. Son yıllarda çok sayıda çalışma ile genişleyen erken modern Osmanlı ve 'kültürel dönüşüm' literatürü çerçevesinde, müzik tartışmalarına giriş mahiyetinde bir değerlendirme sunmayı hedefliyorum. Osmanlı-Türk müziğinin tatmin edici bir tarihinin yazılamamasındaki en büyük sorun yazılı kaynakların (nota derlemeleri) yetersizliği midir? Meşk usulünün pedagojik vasfının dışında aktarım aracı olarak da görev yapması, üsluplardan bahsi imkânsız mı kılmaktadır? Üslup ile ilgili değerlendirmelerde müzik dışı materyallerin kullanılabilirliği nedir? Bugüne kadar tespit edilen dönem kavramları nelerdir ve niçin yaygınlaşamamıştır? Dönemlendirme şart mıdır? Osmanlı tarihyazımında müzik çalışmalarının yeri nedir? Erken modern Osmanlı tanımlamasında müzik ne gibi bir yer kaplamaktadır? Bu gibi sorular etrafında Osmanlı-Türk müziği ve sanatları alanında üretilen bir eserin analizi için tasnif, tasvir yöntemleri sıkıntısını göz önünde bulundurarak, analitik ve diyalektik kuramsal yaklaşımlar etrafında spekülasyonlar üretmeye çalışıyorum. Çalışmada Osmanlı-Türk müziğinin dönemlendirme ile ilgili başlıkları, sanat tarihi ve dönemlendirme çalışmalarının eleştirel kuramları etrafında sergilenmeye çalış1lıyor. Bu makalede amacım, ne yeni bir dönemlendirme önerisi geliştirmek ne de tarih adına yeni bilgiler üretmektir, daha ziyade elimizdeki kaynaklara ve dönemlere nasıl yaklaşılabileceği konusunda deneme niteliğinde bir katkı sağlamaktır.

\section{Bir Tarihsel Zaman Teorisi Olarak Dönem}

Tarihyazımında başvurulan bir yöntem olması hasebiyle dönem kavramına yönelik teorik yaklaşım, tarihyazımına yönelik kuramsal eleştirilere paralel biçimde değişkenlik gösterir. Nesnel tarih anlayışından postmodern tarih anlayışına kadar; klasik tarihselcilik (historisizm), tarihsel sosyoloji, Amerikan toplumsal tarih gelenekleri, Annales ekolü, eleştiri kuramı, toplumsal tarih, Marksist tarih, mikro tarih ve gündelik yaşamın tarihi gibi tüm yaklaşımlar dönem kavramına yönelik farklı bir tutumu barındırır. ${ }^{19}$ Daha derin bir analiz için bu eleştirilerin ve tutumların hepsinin dikkate alınması gerekir. Osmanlı-Türk müziği dönemlendirmesi üzerine düşünürken teorik bir alt yapı oluşturması adına, bu ayrıntılı değerlendirme yerine, kısa ve özel olarak Frederic Jameson'in modernus terimini ele alırken işaret ettiği iki ana eksenden, daha az tartışılmış olan "kavramların zamansal kategorizasyonu"nu (tarihsel zamanı) ele alıyorum, semiyoloji ile yakından ilişkili dilbilimsel boyutu üzerinde ise durmuyorum. ${ }^{20}$

Fernand Braudel, longue durée olarak bilinen "uzun süre" kavramı ile tarihin farklı hız ve ritimde akan zamansallıkları barındırdığını ifade eden ilk tarihçilerden biri olmuştur.

18 Hayden White, Metahistory: The Historical Imagination in Nineteenth-Century Europe (Baltimore: John Hopkins University Press, 1973). 19 Bkz. Georg G. Iggers, Bilimsel Nesnellikten Postmodernizme Yirminci Yüzyılda Tarihyazımı, çev. Gül Çağalı Güven (İstanbul: Tarih Vakfı Yurt Yayınları, 2016).

2o Fredric Jameson, A Singular Modernity: Essay on the Ontology of the Present (Londra: Verso Books, 2002), 18-19. 
150 Yaklaşımının önemli kısmını, tarihsel zamanı; coğrafi zaman, toplumsal zaman (longue durée) ve bireysel zamana (histoire événementielle [olay tarihi]) ayırma girişimi oluşturur. Braudel, histoire événementielle ile kurguladığı kısa süreyi (courte durée) bir çeşit yüzeysellikle tanımlamış, tarihin aslen sosyal bilimler için çatı bir kavram hüviyetini de vurgulayarak, longue durée üzerinde kurgulanması gerekliliğini ifade etmiştir. Dünya tarihini bir değil de birçok nehire benzeten Braudel, longue durée kavramına tutarlı bir geçerlilik kazandırmıştır. Bununla birlikte altını sürekli çizdiği devamlılıktan yana-ve duraklama, kesinti karşıtı-tutumu, tarihsel bazı dönüşümleri kısa zamana ait değişimler ile ifade etmesine de engel olmamıştır. ${ }^{21}$ Braudel'in bahsettiği eş zamanlılık veya çift zamanlılık gibi kavramların üzerinde fazlaca durmaması ise dikkat çekicidir. Bu kavramların anlaşılmasının göründügünden zor olduğuna vurgu yapmakla beraber kendi kendilerini açıkladıklarını da ifade eder. ${ }^{22}$

Öte yandan Reinhart Koselleck ise bu kavramların üzerinde fazlaca durmuş, konu ile ilgili diğer tarihçilerden farkla tarihsel zamana teorik bir yaklaşım getirmeye çalışmıştır. Koselleck'in yaklaşımının temelinde lineer ve homojen bir tarih anlayışının daha karmaşık, heterojen ve çok katmanlı bir zaman anlayışı ile revize edilmesi yatmaktadır. Birçok noktada tarihin ancak ortaya konacak bir tarihsel zaman teorisi ${ }^{23}$ ile varlığını sürdürebileceğini, aksi halde teorisiz bir tarihin sınırsız sorgulamalar içinde kaybolacağını vurgulamıştır. ${ }^{24}$ Koselleck'in klasik dönemlendirme yaklaşımına eleştiri olarak okunabilecek tarihsel zaman teorisi, Anglosakson dünyada ise genellikle bir dönemlendirme teorisi olarak anlaşllmıştır. ${ }^{25}$ Aslında tarih teorisine getirdiği bir dizi farklılık ve ayrım; zaman kavramı ve onun tanımladığ 1 şekilde "doğal kronolojinin tasfiyesi" ile birebir ilişkilidir. Helge Jordheim, Koselleck'in çok net bir şekilde vermediği ve zaman kavramı için vurguladığı çoklu yapıyı şöyle özetler: doğal ve tarihsel zaman, dildışı ve dilbilimsel zaman, diyakronik ve senkronik zaman. ${ }^{26}$ Koselleck, bireysel ve kollektif tecrübe ile ilişkilendirdiği dili, haiz olduğu tecrübenin ardındaki zamansal yapıya işaret etmekle zamanın alanına çeker. Dil-dışı (extralinguistic) ve dilbilimsel (intralinguistic) zaman ayrımları ise tarihin ana malzemesi, kavramlar üzerindeki etkisini teorik bir düzlemde tanımlama çabasıdır. ${ }^{27}$ Koselleck'in eş zamanlılık ile kastettiği şey ise bir bakıma kavram ve söylemlerin belli bir ana bağımlı olarak ele alınması iken diyakroni ile bunun dışında, kavramın geçmişten taşıdığı veya geleceğe yaptığı göndermeleri de içeren bir bakışla ele alınmasıdır. Burada diyakronik zaman ile Braudel'in longue durée'si arasında bir benzerlik dikkati çekmekle beraber Koselleck, üzerinde durduğu atlamalar, kesintiler, geleceğe dair göndermeler ile birlikte daha sofistike bir ayrım yapmaktadır. ${ }^{28}$ Koselleck, Jordheim'ın aracılığı ile dikkat çektiğim üç ayrımı da geçişken bir biçimde farklı şekillerde kullanmıştır.

Tarihyazımı için genel bir teori niteliğindeki bu iki yaklaşımın izlerini Osmanl1-Türk müziği tarihyazımı problemlerinde de sürmek mümkündür; Ali Ufkî ve külliyatının Osmanlı-Türk müziğinin genel tarihi akışı içinde net bir yerde konumlandırılamaması bir bakıma Braudel'in histoire événementielle ile kurguladığ courte durée fenomenine işaret edebilir. Birçok edvarın çağdaşı pratiklere uymayan, 'eskilere' referansla yazılan içerikleri tam da Koselleck'in diyakronik zamanına işaret etmektedir. Farklı üslupların aynı anda var olması ise senkronik zamanla bağlantılandırılabilecek niteliktedir. Sonuç olarak herhangi bir yeni dönem önerisi tüm bu tartışmaları içermedikçe tatmin edici olmaktan uzak kalacaktır.

$\mathrm{Bu}$ pencereden bakınca dönem veya tarihyazımı ile uğraşan araştırmacının çalıştığı ana ve mekâna has durum veya söylemi anlamaya çalışırken önüne çıkan geniş materyal ve kaynağa

21 Fernand Braudel, Maddi Uygarlı; Dünyanın Zamanı, çev. Mehmet Ali Kilıçbay (İstanbul: İmge Kitabevi, 2004), 10. Braudel'in kısa ve uzun zaman arasındaki çelişkili tavrın analizi için bkz. Olivia Harris, "Braudel: Historical Time and the Horror of Discontinuity," History Workshop Journal 57 (Bahar 2004): 161-174.

22 Braudel, Tarih Üzerine Yazılar, 33.

23 Kerstin Behnke'nin çevirisinde "theory of periodization" (dönemlendirme teorisi) olarak yer bulan kavram, Jordheim'in makalesindeki uyarı dikkate alınarak; "tarihsel zaman teorisi" olarak çevrilmiștir.

24 Koselleck, Practice of Conceptual History, 4-20.

25 Helge Jordheim, "Against Periodization: Koselleck's Theory of Multiple Temporalities," History and Theory 51, s. 2 (2012): 151-71, doi:10.1111/j.1468-2303.2012.00619.x.

26 lbid., 161.

27 lbid., 166.

28 Koselleck, Kavramlar Tarihi. 
nasıl yaklaşacağı konusunda da teorik bir yaklaşım geliştirmesi gerektiği açıktır. Tarih, ana malzemesi olarak kurgulanan belge/kaynak yetersizliğinin söz konusu olduğu durumlarda dahi teorik bir yaklaşım çerçevesinde en yakın zaman diliminden geriye dönük bir okuma ile ele alınabilir. ${ }^{29}$ En yakın tarihten geçmişe doğru değişim ve dönüşümleri tespit ettikçe tasnif edilen dönemlerin isimlendirilmesi ve kronolojisi de bir konu olacaktır. Dönem tanımlamaları muhakkak ki birer araç olarak ele alınmalı, "tarihin icat ettiği, ama icat eder etmez elinden kaçan kelimelerin gücü" asla küçümsenmemelidir..$^{30}$ Irving Godt'un belirttiği gibi, "31 Aralık 1599 Cuma günü Rönesans stili ile beste yapan bir bestecinin; ertesi sabah 1 Ocak 1600 Cumartesi günü uyandığında yaptığı besteleri Barok stilinde yapmadığı gayet açıktır." ${ }^{11}$ Kabul etmek gerekir ki geçiş dönemlerinin muğlaklığı nedeniyle zihnimiz daha net, belirgin, baskın bir dönemi kabul etmeye yatkındır. Ancak zihnin bu eğilimi kontrol altına alınarak öncelikli olarak bitiş, başlangıç veya geçiş sekanslarından ziyade dönemin teşekkül ettiği, kendini bulduğu, tamamen tanınıp, tasvir edilebildiği zaman dilimi tanımlanmalı ve buna ek geçiş dönemleri ile sınırlandırılmalıdır. David L. Wagner bunu süreç/ dönem ya da geçişlerin, doruk/zirve noktaları aracılığıyla tanımlanması gerektiği şeklinde vurgular. ${ }^{32}$ Henry L. Clarke, Avrupa müzik tarihini dönemlendirdiği çalışmasında bu zirve dönemi ekseninde belirlediği dönemleri üç ayrı alt dönemle açıklar. Bu alt dönemlerden ilki deneysel/arayış (experimental), ikincisi kurulu/müesses/zirve (established) ve üçüncüsü genişleme/serpilme/detaylanma (elaborate) dönemleridir. Bu dönemler farklı içerikler ile beraber sürekli birbirini takip eder. ${ }^{33}$

\section{“Osmanlı-Türk Müziği” Tanımı}

Osmanlı'da dönem tartışmasına geçmeden önce tercih edilen Osmanlı-Türk müziği isimlendirmesinin üzerinde bir nebze durma ihtiyacı hissediyorum. Kastedilen müziği tanımlamadaki terim anlaşmazlığı henüz tam anlamıyla aşılabilmiş değildir. Dönemsel bir tasnif yerine kavramsal bir tanımı temel alan Osmanlı/Türk müziği teriminin taşıdığı zamansal vurguya dikkat çekmeliyiz. Osmanlı kelimesi kendi başına taşıdığı, zamana koşut imge nedeniyle tarihin belli bir döneminde yaşamış ve ömrünü tamamlamış bir müzik algısının yerleşmesine katkı sağlamıştır-ki bu düşünce Mesud Cemil'den bugüne belli bir taraftar kitlesi de bulmuştur. Bu imgeyi kırmak ve Cumhuriyet döneminde devam eden gelenekle bağı kurabilmek amacıyla, Osmanlı ve Türk ibarelerinin birbirleri yerine kullanılabileceğini ifade eden Osmanlı/Türk müziği tanımı yaygınlık kazanmıştır. Öte yandan bu ana hat, geriye doğru Osmanlı'dan Orta Asya Türk devletlerine uzanan bir çizgisel tarih anlatısını da içermektedir.

Osmanlı/Türk müziği tanımının taşıdığı Osmanlı’yı Türk'e eşleyen etnik vurgu ile farklı etnisitelerin Osmanlı emperyal kültürüne olan katkısının görmezden geldiği iddiasında bulunulabilir. Ancak bu isimlendirme ile kökeni oldukça geriye götürülebilecek fakat kendini tam anlamıyla on yedi ve on sekizinci yüzyıllarda bulduğu kabul edilen, merkezi hiç şüphesiz İstanbul olan ve Rauf Yekta'nın tabiri ile "alimâne musikimiz"34 olarak nitelendirilen müzik geleneğinin Osmanlı ve Türkiye Cumhuriyeti dönemleri tanımlanmaktadır. Bu çalışmada ise kavramsal bir tanımlamadan ziyade dönem içeriklerini temel alarak Osmanlı-Türk müziği tanımı kullanılmaya devam edilmiştir. Nasıl ki Osmanlı dönemine değinmeden bir Kürt veya Rum müziği tarihi yazılamazsa, Osmanlı-Türk müziğinin tarihi de başta Kürt, Ermeni, Rum ve Fars müzikleri olmak üzere, Osmanlı'nın farklı etnik kültürlerinin müziklerini dikkate almadan yazamayacağımızı göz önünde bulundurmak gerekir.

\footnotetext{
29 Léon E. Halkin, Tarih Tenkidinin Unsurları, çev. Bahaeddin Yediyıldız (Ankara: Türk Tarih Kurumu Yayınları, 1989), 136-137. George Kubler da benzer bir perspektifi astronom ile tarihçi arasında kurduğu analoji ile ifade eder. Bkz. George Kubler, The Shape of Time: Remarks on the History of Things (New Haven: Yale University Press, 2008), 17.

3o Lucien Febvre, Rönesans İnsanı, çev. Mehmet Ali Kılıçbay (İstanbul: İmge Kitabevi, 1995), 11.

31 Irving Godt, "Style Periods of Music History Considered Analytically," College Music Symposium 24, s. 1 (1984): 33-48.

32 David L. Wagner, "The Middleness of the Middle Ages: Periodizing European History," Medieval Studies 5, s. 13 (2011): 33-44.

33 Henry Leland Clarke, "Toward a Musical Periodization of Music," Journal of American Musicological Society 9, s. 1 (1956): 25-30.

34 Rauf Yekta, "Ziya Gökalp Bey ve Millî Musikimiz Hakkındaki Fikirleri (I)," Musiki Mecmuast 458 (1997): 6.
} 
Halil İnalcık Osmanlı tarihinde dönemler üzerine yazdığı makalesine şöyle giriş yapar; "[Osmanlı tarihinde dönemler üzerine düşünmek için] öncelikle Osmanlıların kendi tarihlerini dönemlere bölüp bölmediğini tespit etmek, yaşadıkları dönem ile geçmiş dönemler arasındaki bir ayrımın bilincinde olup olmadıkları üzerine düşünmek gerekir."35 İnalcık, yine aynı metinde bu perspektiften belli bir zaman dilimini yeren ya da kutsayan bazı metinlere dikkat çekmiştir. İnalcık'ın aktardığı kaynaklardaki eleştirel tutum, aynı zamanda yaşanan değişimlerin toplumsal karşıllklarını da sergilemektedir. Bu kaynaklar arasından Osmanlı sultanları tarafindan hazırlatılan nasihatnameler ${ }^{36}$ ya da III. Mehmed'in (15931603) yayınlattığı Adâletnâme 37 gibi fermanlar öne çıkmış, "zamanın ruhu" bağlamında okunur olmuşlardır. Çoğunlukla gerileme ${ }^{38}$ (inhitat) paradigması ekseninde ele alınan nasihatname literatürü ve Tanzimat ve Islahat fermanları doğası gereği içerdiği olumsuzluklarla bu paradigmayı destekler bir nitelik kazanmıştır. Dolayısıyla bu kaynaklar hakkınca değerlendirilse dahi görece tek yönlü eğilimleri ile dönemlere has yapıları kavramamıza yeterli olamamıştır.

On dokuzuncu yüzyıla gelene kadar Osmanlı alimleri tarihyazımına, kendilerinden önceki İslami literatür üzerinden; Gazali, Farabi, Nasîrüddin Tûsi, ve İbn-i Haldun gibi alimlerin siyaset teorileri ile yaklaşmışırı. Bunlar arasından Kâtip Çelebi ve Naima bir adım öne çıkar. Kâtip Çelebi ilk kez antropomorfik bir üçlemeyle, büyüme-olgunluk-yaşlllık/gerileme ekseninde Osmanlı tarihini ele almıştır. ${ }^{39}$ Sistematik bir dönem yaklaşımını ise ancak Ahmed Cevdet Paşa ve Mustafa Nuri Paşa gibi Osmanlı tarihçilerinin edimlerinde görebiliyoruz. ${ }^{40}$ On dokuzuncu yüzyll boyunca Ahmed Vefik Paşa, Ahmed Cevdet, Ahmed Midhat gibi birçok tarihçi aynı antopomorfik dönemlendirmeyi temel almıştır. ${ }^{41}$ Bu yaklaşım cumhuriyet ideolojisinin perspektifinde ilköğretim, ortaöğretimde okutulan tarih kitaplarının yazarları Yusuf Akçura ve Abdurrahman Şeref tarafından Yükseliş-Duraklama-Gerileme dönemlendirmesi ile yaygınlığa kavuşmuştur. Son yıllarda ise bu gerileme/çöküş paradigmasının problemli doğası etrafında bir fikir birliği oluşmuş ise de yerine ne konulacağı konusunda henüz bir ortaklık sağlanamamıştır. ${ }^{42}$

Bu gerileme/çöküş paradigmasının tarihyazımına sağladığı kolaylık yaygın bir biçimde kullanılmasına neden olmuştur. Bununla birlikte bu paradigmayı velut bir biçimde var eden bir diğer etken Klasik Dönem/Altın Çağ imgesi ${ }^{43}$ ve birbirlerini besleyen karşıtlıklarıdır. Osmanlı Devleti'nin siyaseten en geniş sınırlara ulaştığı, toplum refahının görece yüksek olduğu kabul edilen on altıncı yüzyıl imgesi bu dönemi Osmanlılar için hep tekrar ulaşılması gereken bir dönem olarak var etmiştir. Ondan uzaklaşılan her tür eylem de gerileme çerçevesinde ve Altın Çağ-Çöküş Dönemi karşıtlığında ele alınmıştır. Altın Çağ kavramını tercih etmeyen çoğu araştırmacı ise Klasik Dönem (1300-160o) tanımını yeğlemektedir. O kadar ki Osmanlı Altın Çağı ya da Klasik Dönemi neredeyse Avrupa tarihinde Rönesans'a denk düşen bir turnusol işlevi görür hale gelmiş, her şey bu dönem etrafında açılanır olmuştur. ${ }^{4}$

35 Halil İnalcık, Essays in Ottoman History (İstanbul: Eren Yayıncılık, 1998), 15-28.

36 Nasihatnamelerin dönem muhtevası üzerine bir analizi için bkz. Erol Özvar, "Osmanlı Tarihini Dönemlendirme ve Nasihat Literatürü," Divan 2 (1999): 135-151.

37 Halil İnalcık, "Adâletnâmeler," Türk Tarih Kurumu Belgeler 2, s. 3-4 (1965): 49-142.

38 Bu tabiri ilk kez kullanan kişi Kantermiroğlu’dur. Bkz. Dimitri Kantemir, Osmanlı Imparatorluğu’nun Yükselis ve Çöküs Tarihi, çev. Özdemir Çobanoğlu (İstanbul: Cumhuriyet Kitapları, 1998).

39 Inalcık, Essays in Ottoman History, 17.

40 lbid., 18.

41 On dokuzuncu yüzyıl boyunca Osmanlı'daki dünya tarihi yazımı girișimleri ve bunların dönemlendirme yaklaşımlarının analizi için bkz. Hakan T. Karateke, "The Challenge of Periodization: New Patterns in Nineteenth-Century Ottoman Historiography," Writing History at the Ottoman Court: Editing the Past, Fashioning the Future, der. Emine Fetvacı ve Erdem Çıpa (Bloomington: Indiana University Press, 2013), 129-154.

42 Linda T. Darling, "Another Look at Periodization in Ottoman History," The Turkish Studies Association 26, s. 2 (2015): 19-28. Gerileme mefhumu ile ilgili bir derleme için bkz. Mustafa Armağan, der., Osmanlı Tarihini Yeniden Yazmak: Gerileme Paradigmasının Sonu (İstanbul: Timaş Yayınları, 2011). On yedinci yüzyıl ekseninde dönemlendirmenin de ele alındığı geniş katılımlı bir çalıştay raporu için bkz. Kahraman Şakul, "Bir Çalıştayın Ardından. 17. Yüzyılda Osmanlı İmparatorluğu: Kriz ve Dönüşüm," Toplumsal Tarih 223 (2012): 22-38. Güncel olarak da tarih çalışmaları yüzyıl temelli dönem tanımlamaları kullanmaktadır.

43 'Altın Çă̆' imgesinin analizi için bkz. Cemal Kafadar, "The Myth of Golden Age: Ottoman Historical Conciousness in the Post Süleymânic Era," Süleymân the Second and His Time, der. Halil İnalcık ve Cemal Kafadar (İstanbul: The Isis Press, 1993), 1-19. 44 Özel, Dün Sancısl. 
Osmanlı mimarlık tarihi yazımı da ilk örneği Usûl-i Mîmârî-i Osmânîde görülen;45 aynı klasik dönem imgesi etrafında dönmektedir. Osmanlı İmparatorluğu’nun katıldığı 1873 Viyana Dünya Sergisi’nde sunulmak için Avrupa'daki benzerleri örnek alınarak hazırlanan bu çalışma ile özgün Osmanlı mimari üslubunun varlığı ispatlanmaya çalışlır. ${ }^{46} \mathrm{Bu}$ çaba dâhilinde sistematik bir dönemlendirmeye gidilmemekle birlikte siyasi tarihe paralel kuruluş dönemi ardından Osmanlı mimari üslubunun olgunlaştığı, zirve/klasik dönem imgesi korunmuştur. Mimar Sinan ile olgunlaştığı kabul edilen Osmanlı mimari üslubu, on sekiz ve on dokuzuncu yüzyıllarda gerileme/çöküş dönemine paralel biçimde bir değişim gösterir. Klasik dönem üslubundan bir sapma olarak görülen bu değişim gayrimüslim mimarların artan etkinliklerine indirgenmiştir. Öte yandan on sekiz ve on dokuzuncu yüzyıllara sıkıştırılan Osmanlı modernleşmesinin ele alınış şeklinin bu gerileme imgesinin yerleşmesine katkısı da göz ardı edilemez. Özellikle Avrupa-merkezli sanat tarihi yazımında İslam, Hint, Çin gibi Avrupa dışı kültürlerin modernliği ithal biçimde yaşadıkları yargısı ile 'klasik' dönemlerine, 'altın' çağlarına yoğunlaşılmış, geri kalan dönemleri dikkate alınmamış, alındığı zamanlarda da bu dönemlere referansla değerlendirilmiştir. Son yıllarda dünya sanat tarihini ele alan çalışmalardaki bu eğilimleri ortaya koyan çokça eleştirel çalışma bu bakış açısının revize edilmesinin önünü açmıştır. ${ }^{47}$

Usûl-i Mîmârî̀-i Osmânîde atılan ilk adım on dokuzuncu ve yirminci yüzyıllarda farklı perspektiflerle tekrar ele alınmasına rağmen, gerileme/çöküş dönemi imgesi ve on sekizinci ve on dokuzuncu yüzyıllara atfedilen bozulma imajı büyük ölçüde kendini korumayı başarabilmiştir. Osmanlı aydını için altın çağdan bir uzaklaşma, Cumhuriyet ideolojisi için milli bir kimlik oluşturma çabası ve yeninin kutsanması gibi eğilim ve kabullerin hepsi bu algının devamlılı̆̆ını sağlayan unsurlar olmuştur. Halen etkisini yitirmeyen bu imaj, Usûl-i Mîmârî̀-i Osmânîden sonra, Celal Esad Arseven tarafından ulusalcı bir çizgide tekrar ele alınmıştır. Arseven, Osmanlı dönemi Türk sanatını şu evrelere ayırır; (1) Bursa üslubu (13251501): Bursa'nın alınmasından İstanbul'da Bayezid Camii'nin yapılmasına kadar (2) Klasik üslup (1501-1616): Bayezid Camii'nden Sultan Ahmed Camii'nin yapılmasına kadar; (3) Yenileştirilen klasik üslup (1616 -1703): Sultan Ahmed Camii ile başlayıp III. Ahmed devrine kadar; (4) Lâle Devri ${ }^{48}$ üslubu (1703-1730): Ill. Ahmed devri; (5) Barok üslup (1703-1808): I. Mahmud ve III. Selim devirleri; (6) Ampir ve yabancı Rönesans üslubu (18o8-1874): II. Mahmud ve I. Abdülmecid ile başlayıp Abdülaziz saltanatının başına kadar süren devre; (7) Yeni klâsik üslûp (1875-1923): Çırağan Sarayı'nın yaptırılmasından Cumhuriyet'e kadar. ${ }^{49}$ Arseven'in çizdiği bu çerçeve günümüzde de yaygın bir kabul görmektedir. Bu dönemlendirme ile Osmanlı mimarlığının zirve dönemi için klasik üslup/dönem terimini kullanan ilk kişi Arseven olmuştur. Arseven, Lale Devri ve onu takip eden Barok, Ampir üsluplarını Batı etkisine bağlı "sanatta çöküntünün başlangıcı" ile özetlerken Türk sanatçıların bu üslupları kendilerine göre yeniden yorumladığını da eklemiştir..$^{50}$ Arseven’den sonra Doğan Kuban özellikle Osmanlı Baroğu üzerine yaptığı çalışmalarla dönem imgesini bir nebze olumlamaya çalışmış, bu dönemlerin "sanat tarihimizde şerefli bir yer" edinmeleri gerektiğini vurgulamıştır..$^{51}$

45 Victor-Marie de Launay et al., Osmanlı Mimarisi: Usul-i Mi'mari-i Osmani, der. Raşit Gündoğdu et al. (İstanbul: Çamlıca Yayınevi, 2011); ayrıca bkz. Bülent Tanju, der., Tereddüd ve Tekerrür: Mimarlk ve Kent Üzerine Metinler: 1873-1960 (İstanbul: Metis Yayınları, 2007). Metnin daha ayrıntılı bir değerlendirmesi için bkz. Ahmet Ersoy, "On the Sources of the 'Ottoman Renaissance': Architectural Revival and its Discourse During the Abdülaziz Era (1861-1876)" (doktora tezi, Harvard University, 200o).

46 Böyle bir ihtiyacı doğuran on dokuzuncu ve yirminci yüzyıl İslam sanatı/mimarlığı tarihyazımının kısa bir özet için bkz. Gülru Necipoğlu, "Creation of a National Genius: Sinan and the Historiography of 'Classical' Ottoman Architecture," Muqarnas 24 (2007): 141-183. Aynı özgün Osmanlı geleneğinin ispatı çabası Osmanlı-Türk müziği kuramının kurucu isimleri olarak nitelendirilebilecek, Rauf Yekta, Hüseyin Sadettin Arel ve Suphi Ezgi'nin standardizasyon üzerine yaptıkları çalışmalarda da görülebilir.

47 Bkz. Robert S. Nelson, "The Map of Art History," The Art Bulletin 79, s. 1 (1997): 28-40.

48 Lale Devri tanımına ilk kez yirminci yüzyıl başında Yahya Kemal Beyatlı ve Ahmed Refik Altınay’ın çalışmalarında rastlanılır. Bkz. Abdülkadir Özcan, "Lâle Devri," Islam Ansiklopedisi, erişim tarihi 17 Kasım 2019, https://islamansiklopedisi.org.tr/lale-devri\#1. Lale Devri'ne atfedilen Osmanlı modernleşmesinin ilk adımı ve zevk, safahat düşkünlüğü gibi tutarsız anlamların değerlendirmesi için bkz. Can Erimtan, "The Sources of Ahmed Refik's Lâle Devri and the Paradigm of the "Tulip Age': A Teleological Agenda," Essays in Honour of Ekmeleddin Ihsanoglu, der. Mustafa Kaçar ve Zeynep Durukan (İstanbul: IRClCA, 2006), 259-278.

49 Celâl Esad Arseven, Türk Sanatı (İstanbul: Cem Yayınevi, 1984).

50 Shirine Hamadeh'in deyimiyle "bu modası geçmiş ama hala geçerliliğini koruyan kanaat” özellikle kendisinin çalışmaları ile bir nebze olsun revize edilmiş görünüyor. Bkz. Shirine Hamadeh, Şehr-i Safa, 18. Yüzyllda İstanbul, çev. Illknur Güzel (İstanbul: İletişim Yayıncilık, 2010).

51 Doğan Kuban, Türk Barok Mimarisi Hakkinda Bir Deneme (İstanbul: Pulhan Matbaas1, 1954). 
Giriş bölümünde bahsedilen tarihyazımındaki problemlere rağmen Osmanlı-Türk müziğinin dönemlendirme açısından sunduğu renkli resim daha da dikkat çekicidir. Öyle ki bugüne kadar ortaya konan birçok dönemlendirme önerisine ek olarak halen farklı öneriler geliştirilmeye devam edilmektedir. ${ }^{52}$ Bunun yanında bugüne kadar önerilen dönemlendirmelerin genel bir dökümü üzerine neredeyse aynı isim ve içerikle üç farklı yüksek lisans tezi gerçekleştirilmiş olması, güncel çalışmalar hakkında bir kanaat sunmakla beraber, dönemlendirmenin üzerindeki "faydasız bir uğraş"’3 yargısına rağmen fazlasıyla ilgi çeken bir konu olduğunu da gösterir niteliktedir.54

On yedi ve on sekizinci yüzyll müelliflerinden Şeyhülislam Esad Efendi, Kantemiroğlu ve Hızır Ağa’nın da dillendirdiği "Eskiler" (mütekaddimîn) ve "Yeniler" ayrımı, Osmanlı-Türk müziği için adı koyulabilen ilk dönem tasviri olarak değerlendirilebilir. Ancak bu tasvir bir dönemlendirme çabasından ziyade eski edvar geleneğinin, çağdaş üretimlere ters düşen tanımlamaları ile araya çizilen bir ayrımı ifade etmektedir. ${ }^{55}$ Daha detaylı bir dönemlendirme ibaresine ise Abdülbâki Nasır Dede'nin (1765-1822) Tedkîk ü Tahkîk'inde rastlanılır. Nasır Dede de bu eserde başı sonu belli bir dönemlendirme girişiminde bulunmamaktadır fakat eser boyunca farklı dönemlere ait edvarların içeriklerinden ve farklı nazari tanımlamalardan bahsetmektedir..$^{5}$ Yalçın Tura geriye doğru giderek bu tanımların geçtiği edvarları ve müelliflerini tespit etmiştir. Yalçın Tura'nın tespit ettiği bu dönemler daha sonra birkaç yazar tarafından da tekrar ele alınmıştır. ${ }^{57}$ Diğer yazarların tespitleri ve Tura'nın bu dönem tasvirlerine uygun düştüğünü düşündüğü edvar müellifleri ile dönemlerin yaklaşı tarih aralıkları aşağıdaki Tablo ı'e aktarılmıştır. Böylece Nasır Dede’nin bu sıfatları kullandığı dönemlerin bir kronolojisi çıkarılarak, en azından fikir vermesi adına zihninde az çok teşekkül etmiş olan dönemlendirmeyi görebilme şansı elde edilmiştir.

\begin{tabular}{llc}
$\begin{array}{l}\text { Abdülbâki Nasır Dede } \\
\text { Akdemûn (en eskiler) }\end{array}$ & Yalçın Tura'nın Notları & Yaklaşık ola \\
$\begin{array}{l}\text { Kudemâ-i Mütekaddimîn } \\
\text { (öncekilerin eskileri) }\end{array}$ & Farabi (951)'ye kadar & -1300 \\
$\begin{array}{l}\text { Kudemâ (eskiler) } \\
\text { Kudemâ-i müteahhirîn } \\
\text { (sonrakilerin eskileri) }\end{array}$ & $\begin{array}{l}\text { Safiüddin (1252-1334) } \\
\text { ve onun yolundan gidenler }\end{array}$ & $1300-1200$ \\
$\begin{array}{l}\text { Müteahhirîn (sonrakiler) } \\
\begin{array}{l}\text { Mütekaddimîn-i Selef } \\
\text { (bizden öncekilerden öncekiler) }\end{array}\end{array}$ & $\begin{array}{l}\text { Lâdikli Mehmed Çelebi (1440) } \\
\text { ve ondan sonra gelenler }\end{array}$ & $1400-1450$ \\
$\begin{array}{l}\text { Eslaf } \text { (bizden öncekiler), } \\
\text { Müteahhirîn-i Selef } \\
\text { (bizden öncekilerin sonrakileri) }\end{array}$ & Nâyî Osman Dede ve Kantemiroğlu & $1450-1510$ \\
$\begin{array}{l}\text { Fî zemâninâ (günümüzde) } \\
\text { Dahnemi }\end{array}$ & Ill. Selim Dönemi & $1510-1650$ \\
\hline
\end{tabular}

Tablo 1: Abdülbâki Nasır Dede'nin dönem sıfatları

52 Yakın tarihli yeni bir dönemlendirme önerisi için bkz. Recep Uslu, “Türk Müziği Tarihinde Yeni Bir Dönemlendirme Önerisi,” Medeniyet Sanat 1, s. 2 (2015): 91-109.

53 Donald R. Kelley, "Periodization," New Dictionary of the History of Ideas, der. Maryanne Cline Horowitz (Michigan: Thomson Gale, 2005), 1730-1732.

54 Şirin Karadeniz, "Türk Müziğinde Dönem Anlayışı" (yüksek lisans tezi, İstanbul Teknik Üniversitesi, 2007); Oya İşboğa, "Türk Mûsiki'nde Tarih Sinıflandırmaları" (yüksek lisans tezi, Haliç Üniversitesi, 20o8); Berat Gürcan Yaman, "Türk Müziğinin Devirleri" (yüksek lisans tezi, Haliç Üniversitesi, 2007).

55 Abdülkadir Tekin, Türk Musikisinde Nağmeler ve Makamlar; Kemânî Hızır Ağa'nın Tefhimü’l Makâmât fî Tevlîdi’n Nagâmât İsimli Edvâr'ı Örneğinde 18. Yüzyll Türk Mûsikîsi (ìstanbul: Büyüyenay Yayınları, 2015), 115-118.

56 Nasır Dede'nin kendisinin hiçbir edvar müellifi veya bestekâr ismini anmadığına dikkat çekmek gerekir.

57 Nasır Abdülbâki Dede, Tedkîk ü Tahkîk, haz. Yalçın Tura (İstanbul: Pan Yayıncılık, 2006). Diğer örnekler için bkz. Fatma Adile Başer, Türk Mûsikîsinde Abdülbâkî Nâsır Dede: Abdülbaki Dede'nin Hayatı ve "Tedkîk u Tahkîk" (ìstanbul: Fatih Üniversitesi Yayınları, 2013); Ozan Yarman, "Makam Kuyumcuları," Saz ve Söz Internet Dergisi (Nisan 2019), erișim tarihi 17 Kasım 2019, www.ozanyarman.com/files/ kuyumcular.pdf. Ayrıca bkz. Nilgün Doğrusöz, "History of Ottoman/Turkish Music Theory," Writing the History of "Ottoman Music," der. Martin Greve, çev. Efkan Uğuz, Martin Greve ve Onur Nobrega (Würzburg: Ergon-Verlag, 2015), 84. 
Özellikle Feldman'ın peşrevler üzerinde yaptığı ve Tablo 3’te sunulan dönemlendirmesi ile Nasır Dede'nin Mütekaddimîn-i Seleften sonra çizdiği dönemler arasındaki paralellik dikkat çekicidir. Ancak şunu da eklemek gerekir ki, Nasır Dede'nin zihninde olduğunu varsaydığımız bu dönemlendirme, doğrudan üsluba ilişkin olmaktan uzak, edvar yazım geleneklerinin farklılıkları üzerinde şekillenmektedir. Illginç olan bu kadar ayrıntılı bir dönem tasvirine Cumhuriyet dönemine kadar rastlanılmayacak olmasıdır.

Cumhuriyet dönemine gelindiğinde ise başta Ercüment Berker, Yılmaz Öztuna, Nazmi Özalp, Onur Akdoğu ve Cinuçen Tanrıkorur gibi önemli müzik araştırmacıları farklı dönem yaklaşımları sergilemiştir. Popülerlik kazanan Berker'in dönemlendirmesi haricinde ayrı ayrı içeriklerini vermeye gerek duymadığım bu dönemlendirmelerin ayrıntılı bir derlemesi için Şirin Karadeniz'in yüksek lisans tez çalışmasına başvurulabilir. ${ }^{8}$ Bu dönem önerileri arasında en yaygın kullanılanı Ercüment Berker'in Preklasik, Klasik, Neoklasik, Romantik ve Reform dönemlendirmesidir. ${ }^{59}$

Hazırlayıcı Dönem
Ilk Klasik Dönem
Son Klasik Dönem
Neoklasik Dönem
Romantik Dönem
Reform Dönemi

Başlangıçtan
Meragi
Itrî
İsmail Dede
Zekai Dede
Hüseyin Sadettin Arel

\author{
Meragi \\ Itrî \\ İsmail Dede \\ Zekai Dede \\ Hüseyin Sadettin Arel \\ Günümüz
}

Tablo 2: Ercümend Berker'in dönemlendirmesi

Berker'in dönemlendirmesinin tarihyazımında pek kabul görmeden müziğin uygulamalı alanlarında (konser, albüm, radyo programı isimleri gibi) yaygınlı kazanması ise ancak bu kavramlara yönelik popüler ilgi ile açıklanabilir. Bunun yanında 1970'lerden bu yana Osmanlı-Türk müziği eğitimi için bir merkez haline gelen İstanbul Teknik Üniversitesi Türk Musikisi Devlet Konservatuarı eğitim programında bir dönem yer alması da Berker'in dönemlendirmesini yaygınlaştırmıştır. ${ }^{60}$ Avrupa müziği dönemlerine referansla ${ }^{61}$ geliştirilen dönem başlıkları alanda belli bir beklentiyi karşılamış görünmektedir. Öte yandan Osman11-Türk müziği dönemlendirme yaklaşımlarının sayıca çokluğu açık bir tatminsizliğe işaret etmektedir. Buna rağmen her yeni dönem önerisi aynı kısıtlı kaynak üzerinde-zaman zaman ona dahi ihtiyaç duymadan - hareket etmiş, kaynakların yeniden değerlendirilmesi, çeşitlendirilmesi dönemleri tespit için ayrı bir gözle ele alınması gibi eğilimler pek rağbet görmemiştir. Ortaya atılan dönem önerileri de yüzeysel yargılarla kısıtlı kalıp, üslup analizleri ile temellendirilebilmiş değildir. Belli bir döneme has üslup farklarının tespiti üzerine ilk ciddi araştırmalar Owen Wright ${ }^{62}$ ve Walter Feldman tarafından yapılmıştır. ${ }^{63}$ Owen Wright'n özellikle 1988 yılında yayımlanan çalışması Osmanlı-Türk müziğindeki değişimlerin melodik yoğunluk ve ritmik değişim ekseninde incelendiği ilk çalışmadır. ${ }^{64}$ Bunların yanında, Mehmet Uğur Ekinci’nin yine teknik analizlerle desteklediği kıymetli çalışmaları ve Cem Behar’ın özellikle geçiş dönemleri üzerine edimleri ile Osmanl1-Türk müziği tarihi yazımında birçok sorunlu alana işaret ettiği, öncü nitelikli çalışmaları da anılmalıdır. ${ }^{65}$ Osmanl1-Türk müziğinin yaşadığı değişimler üzerine başta bahsi geçen yazarlar olmak

\footnotetext{
58 Temellendirilmesi pek mümkün olmayan bu dönemlendirmelerin derinlemesine bir değerlendirmesi bu çalışmada sunulmamıştır. Böyle bir çalışma için bkz. Sirin Karadeniz, "Türk Müziğinde Dönem Anlayışı."

59 Ercümend Berker, "Türk Musikisinde Dönemler," Erdem Dergisi 1, s. 1 (1985): 147-168.

6o Konservatuar eğitim programı dahilindeki ders içerikleri uzunca bir süre boyunca Berker'in dönemlendirmesi çerçevesinde yürütülmüştür ancak 2000 yllında bu dönemlendirmeden vazgeçilerek, eğitim programı yüzyıllara dayalı olarak revize edilmiştir. 61 Bu yaklaşımın eleştirisi için bkz. Ruhi Ayangil, "Thoughts and Suggestions on Writing Turkish Music History," Writing the History of Ottoman Music, 53.

62 Owen Wright, Demetrius Cantemir: The Collection Of Notations Part 2: Commentary (Farnham: Ashgate Publishing, 20oo).

63 Özellikle Walter Feldman'ın eser analizleri, tarihi, edebi ve görsel kaynaklardan beslendiği "Music of Ottoman Court" kitabı birçok eksiğiyle beraber hâlâ alandaki en temel başvuru kaynağı niteliğindedir ve halen Türkçe okurun dikkatine sunulmamış olması alandaki ciddi bir eksiklik olarak durmaktadır. Bkz. Walter Feldman, Music of the Ottoman Court: Makam, Composition and the Early Ottoman Instrumental Repertoire (Berlin: VWB-Verlag für Wissenschaft und Bildung, 1996).

64 Owen Wright, "Aspects of Historical Change in the Turkish Classical Repertoire," Musica Asiatica 5, der. Richard Widdess (Cambridge: Cambridge University Press, 1988), 1-108.

65 Bkz. Mehmet Uğur Ekinci, "The Kevserî Mecmûası Unveiled: Exploring an Eighteenth-Century Collection of Ottoman Music," Journal of the Royal Asiatic Society 22, s. 2 (2012): 199-225, doi:10.1017/S1356186312000259; "Kantemiroğlu Notalarının Bilinmeyen Bir Nüshas1," Musikişinas 13 (2015): 75-125; Cem Behar, Musikiden Müziğe, Osmanll/Türk Müziği: Gelenek ve Modernlik (İstanbul: Yapı Kredi Yayınları,
} 
156 üzere birçok araştırmacı farklı kanaatler sunmuştur ancak gerek henüz yeterli birikimin oluşmaması gerekse de dönem tanımlamasının keskin ve iddialı mahiyeti, bu yazarların dönemlendirmeden uzak durmasına neden olmuştur. Bir analizle temellendirilebilmiş ilk dönemlendirmeyi Walter Feldman 1996 yılında yayımlanan kitabında sunmuştur. Kitabının giriş kısmında verdiği jenerik mahiyetindeki dönemlendirmeye ek olarak peşrev ve semailer üzerine detaylı bir dönemlendirme analizine de yer vermiştir. Ali Ufkî ve Kantemiroğlu külliyatında yer alan eserlerin form, makam ve seyir analizi üzerine temellendirdiği bu ilerlemeci dönemlendirmeyi aşağıdaki Tablo 3’te özetlemeye çalıştım.
1. Dönem (1500-1550)
Acemler-Hindûyân
(I. Selim ve I. Süleyman Dönemlerinde Fars Müzisyenler)
Sürekli tekrar ve kopya edilen yarım ya da bir ölçülük nağme anlayışı.
2. Dönem (1550-160o)
Türk ve Yabancı Müzisyenler (Hasan Hac, Emir-i Hac, Gazi Giray Han)
Bir ölçüyü aşan daha uzun nağmeler.
3. Dönem (1600-1650)
Türk ve Fars Müzisyenler
(IV. Murad, Solakzâde, Mıskalî Ahmed Bey, Şâh Kulu, Haydar Can)
Azalan tekrarlı nağmeler ve 5-10 ölçülük uzun inici nağmeler.
Terkib ayırımı.
4. Dönem (1650-1690)
IV. Mehmed, Muzaffer, Neyzen Ali Hoca, Angeli, Osman Dede
Tekrarlı nağmeler neredeyse yok olur. Yeni makam anlayışına uygun seyir. Uzun nağmeler. Tempo yavaşlamasının ve nağme yoğunluğu artışının başlangıcı.
5. Dönem (1690-1710)
Kantemiroğlu
Modern seyir anlayışı. Geçkinin yaygınlaşması. Daha uzun peşrevler.
Düşük tempo ve yoğun nağme tercihi.

\author{
6. Dönem (1710-1780) \\ 7. Dönem (1780-1815)
}
I.Mahmud, Kevseri
Nağme yoğunluklarında ve geçkilerde belirgin bir artış.
III. Selim, Tanburi İsak
Tüm peşreve yayılan melodik genişleme ve
geçkinin ikincil plana geçmesi.
8. Dönem (1815-1850)

\begin{abstract}
Numan Ağa, Zeki Mehmed Ağa, Osman Bey
Modern dönem, usullerin sabitlenmesi, hanelerin eşit uzunluğa gelmesi ve bileşik makamların öne çıkması.
\end{abstract}

Tablo 3: Walter Feldman'ın peşrevler üzerine kurguladığı dönemlendirme

Feldman'ın bu ufuk açıcı üslup analizi, üzerinde tartışılmaya değer ilk dönemlendirme önerilerinden biridir. Ancak bu önemli dönem analizinde sunulan analitik yaklaşım ile yazarın sezgilerine dayalı kabulleri bir nebze birbirine karışmış görünmektedir. Çok daha detaylı bir diğer eser/üslup analiziyle temellendirilmiş öneri de Feldman'ın yukarıda verilen dönem analizinin birçok kusurlu ve yüzeysel tarafına dikkat çeken Owen Wright tarafından geliştirilmiştir. ${ }^{66}$ Yine Feldman gibi ilerlemeci bir yaklaşımda bulunan Wright, ${ }^{67}$ erken dönem eserleri üzerinde yaptığı usul, seyir ve melodi yoğunluğu analizleri ile 170o'den sonra her yarım yüzyılda melodilerin düzenli olarak yüzde kırk oranında ağırlaştığını ve detaylandığını öne sürmüştür. ${ }^{68}$

İki yazarın da tüm bu değerlendirmeleri yaparken on sekizinci yüzyıl müziği için kullana- 
bildikleri kaynaklar Kevserî Mecmuası'ndan o güne kadar yayımlanmış olan birkaç peşrev ile sınırlıdır. Bu peşrevlerden diğer kaynaklarda yer almayan Nihavend Peşrevi, öteki peşrevlere göre melodik yoğunluk ve seyir bakımından belli farklılıklar göstermektedir. Eldeki bu tek ve farklı kaynak üzerinden bir dönem tasviri yapmak zorunda kalan iki yazar da bu peşrev üzerinden benimsedikleri gelişmeci/evrimci teoriyi destekler nitelikte yorumlar geliştirmişlerdir. Öyle ki Feldman, 5. Dönem olarak belirttiği Kantemiroğlu ${ }^{69}$ döneminden sonra Osmanl1-Türk müziğinde yeni bir dönemin geldiğine işaret etmiştir.

Yakın zamanda Mehmet Uğur Ekinci, önce Kevserî Mecmuası üzerine yazdığı bir makale ardından mecmuada yer alan tüm nota külliyatını içeren bir CD ile beraber yayımladığı kitabı, bu kıymetli yazmanın üstündeki sır perdesini büyük ölçüde kaldırmış görünmektedir. Özellikle yazdığı makalede Mecmua-ı Saz-ü Söz, Kantemiroğlu Edvâr'ı ve Kevserî Mecmuası'nda ortak olarak bulunan eserler üzerinde yaptığı karşılaştırmalar, başta Feldman ve Wright tarafından ortaya atılan teorilerin gözden geçirilmesi gerekliliğini vurgulamıştır. ${ }^{70}$ Ekinci'nin ikna edici yorumları on sekizinci yüzyıl ile ilgili bugüne kadarki değerlendirmelerin yeniden ele alınması ihtiyacını doğurmakla birlikte, melodik yoğunluk artışı ve ritmik ağırlaşma teması halen Osmanlı-Türk müziğinin longue durée fenomeni olarak yerini korumaktadır. Yine Ekinci'nin de bahsettiği nota müelliflerinin eserleri notaya alırken gösterdikleri detay tercihleri ciddi önem taşımakta ve Koselleck'in üzerinde durduğu farklı zamansallıklara işaret etmektedir. ${ }^{71}$ Ekinci'nin eleştirilerini dikkate almış görünen Feldman'ın, daha yakın tarihli bir makalesinde bu sefer on yedinci yüzyılın son çeyreğinde başlattığı dönüşüm sürecini on dokuzuncu yüzyıla kadar uzattığı görülmektedir.72 ilk üslup analizi girişimleri ile aşama aşama bir yol kat edilmesine imkân sağlayan, özellikle Owen Wright'in her eser üzerinde büyük uğraşlar vererek sergilediği bu analiz ${ }^{73}$ ve sorgulamaların daha geniş kapsamlarda gerçekleştirilmesine ihtiyaç vardır. Buna imkân sağlayabilecek hesaplamalı müzikoloji (computational musicology) çalışmaları halen dönem ve geçiş olgularını anlamamız için büyük bir fırsat olarak durmaktadır. ${ }^{74}$

\section{Değerlendirme}

Dönem tanımlamalarının başarısında faydalanılan kaynakların çeşitliliği öncelikli bir yer tutar. Bu çeşitlendirilen kaynaklar karşılaştırmalı ve paralel okumalar ile ele alınırken başta Koselleck'in üstünde durduğu tarihi zamansal nitelik ve Braudel'in "dünya tarihi bir nehir değil de birçok nehirdir”75 diyerek vurguladığı farklı üslupların eşzamanlılığı her daim dikkate alınmalıdır. Değişim noktalarının/süreçlerinin tespiti ${ }^{76}$ farklı disiplinlerin literatürü ile desteklenmelidir. Özellikle kültür tarihi yazımı ancak bu çerçevede ele alınabilir. Bu çalışmada kısaca bahsedilen tarih, mimarlık ve müzik, tarihyazım çalışmalarında görece/ yaygınlıkla kabul görmüş - ve son yıllardaki eleştirel çalışmalarla hızla etkinliklerini kaybeden-dönemlendirmeleri Tablo 4'te sıralanmıştır.

Tablo genel olarak değerlendirildiğinde tüm disiplinlerde aynı lineer çizginin takip edilmiş

69 Feldman, Kantemiroğlu'nu Buhurîzâde Itrî Efendi ve Dede Efendi’nin sözlü müzikte, Tanburi İzak'ın da saz müziğindeki edindikleri konumlara yakın bir önem taşıdığını ifade eder. Bkz. Feldman, Music of the Ottoman Court, 391.

7o Ekinci, "Kevserî Mecmûası Unveiled”; Ekinci, Kevserî Mecmuası.

71 Farklı zamansallıklara dikkat çekerek saba makamı özelinde makam kavramının tarihsel perspektifle ele alınması gerekliliğini vurgulayan kıymetli bir çalışma için bkz. Jacob Olley, "Modal Diversity in Early Ottoman Music: The Case of Makâm Sabâ," NEMO-Online 1, s. 1 (2012): 35-50.

72 Aynı șekilde Kantemiroğlu’na verdiği bu dönüșümün bayrağını, Koca Osman’a devretmiş gibidir; Feldman, “The Musical 'Renaissance,” 98. Feldman'ın aynı metinde kullandığı ve başlık olarak seçtiği "Rönesans" tanımlamasına ise ayrıca değinmek gerekir. Bu gibi birçok çağrışıma haiz, içeriği günden güne değişen geniş içerikli ithal kavramların kullanımı çoğunlukla tatminkâr sonuçlar doğurmamıştır. Feldman da kavramın haddini aşabileceğini ifade etmekle beraber kullanmaktan da geri durmamıştır. Bkz. ibid., 136.

73 Wright, Demetrius Cantemir pt.2.

74 Türk Müziği merkezli hesaplamalı müzikoloji çalışmalarının genel bir özeti için bkz. Barış Bozkurt, Ruhi Avangil ve André Holzapfel, "Computational Analysis of Turkish Makam Music: Review of State-of-the-Art and Challenges," Journal of New Music Research 43, s. 1 (2014): 3-23, doi:10.1080/09298215.2013.865760. Benzer çalışmalar için bir kaynak oluşturması amacıyla gerçekleştirilen, Türk Müziği külliyatını örnekleyen bir veri tabanı projesi olan SymbTr için bkz. M. Kemal Karaosmanoğlu, "A Turkish Makam Music Symbolic Database for Music Information Retrieval: SymbTr," Proceedings of ISMIR 2012, erișim tarihi 17 Kasım 2019, https://ismir2012.ismir. net/event/papers/223_ISMIR_2012.pdf. Ayrica bkz. Burak Uyar et al., "A Corpus for Computational Research of Turkish Makam Music," Proceedings of the 1st International Workshop on Digital Libraries for Musicology - DLfM '14 (New York: ACM Press, 2014), 1-7, doi:10.1145/2660168.2660174. SymbTr örneğinde olduğu gibi bugüne kadar benzer çalışmalarda çoğunlukla on dokuz ve yirminci yüzyıl eserleri üzerinde çalışılmıştır. Erken dönem kaynaklarına yoğunlaşan bir hesaplamalı müzikoloji çalışmasının ise bu makalenin giriş bölümünü oluşturduğu tez kapsamında gerçekleștirilmesi planlanmıștır.

75 Braudel, Maddi Uygarlk, 10.

76 Wagner, "The Middleness of the Middle Ages." 


\begin{tabular}{|c|c|c|c|c|c|}
\hline & & & Mimarlık & \multicolumn{2}{|c|}{ Müzik } \\
\hline Yüzyıl & & & Celal Esad Arseven & Ercïmend Berker & Walter Feldman \\
\hline 13 & \multirow{3}{*}{ Kuruluş Dönemi } & & - & Hazırlık Dönemi & - \\
\hline 14 & & \multirow{3}{*}{ Klasik Dönem } & & \multirow{4}{*}{ Preklasik Dönem } & Geç Ortaçă̆ \\
\hline 15 & & & & & Geçiş \\
\hline 16 & Yükselme Dönemi & & Klasik Üslup & & Erken Modern \\
\hline 17 & \multicolumn{2}{|c|}{ Duraklama Dönemi } & Yenileștirilen Klasik Üslup & & \multirow{4}{*}{ Modern } \\
\hline 18 & \multicolumn{2}{|c|}{ Gerileme Dönemi } & $\begin{array}{l}\text { Lale Devri } \\
\text { Barok Üslup }\end{array}$ & \multirow{2}{*}{ Klasik Dönem } & \\
\hline 19 & \multirow{4}{*}{\multicolumn{2}{|c|}{ Dağıııma ve Çöküş Dönemi }} & Ampir ve Yabancı Rönesans & & \\
\hline & & & Ssiunu & Neoklasik Dönem & \\
\hline \multirow{2}{*}{20} & & & \multirow{2}{*}{ Yeni Klasik Üslup } & Romantik Dönem & \multirow{2}{*}{ Klasik Türk Müzi } \\
\hline & & & & Reform Dönemi & \\
\hline
\end{tabular}

olması beklenmese dahi özellikle Osmanlı-Türk müziği tarihyazımında klasik üslubun hâkim olduğu kabul edilen dönem ile tarihyazımında klasik dönem (altın çağ) olarak ifade edilen zaman dilimleri arasındaki fark dikkat çeker. Neredeyse iki yüzyılla ifade edilen bu fark, kabul edilebilecek bir faz farkından öte bir anlam taşımaktadır. Tülay Artan'ın "Gecikmiş Osmanlılaşma"77 tabiri ile tanımladığı bu durumu Cem Behar, ibn Haldun'u hatırlatarak, özgün Osmanl1-Türk müziği geleneğinin gelişmesi için devletin siyasal gücü doruğa çıtıktan sonra iki buçuk asır geçmesi gerektiği şeklinde açılkar. ${ }^{78}$ "Kültürel mirasın" birikmesi fikri ile paralel bu Bourdieucü yaklaşım kendi içerisinde tutarlı görünmekle beraber klasik dönem tanımlaması ile bir hesaplaşmaya girişmemekte, asıl aydınlatılmasına ihtiyaç duyulan on beşinci yüzyıl sonrası ile on yedinci yüzyıl ortalarından önceki kültürel ortama dair gayr-i muayyen bir yargı taşımaktadır. Bunun yanında on altıncı yüzyılda edebiyat alanında yaşandığı kabul edilen Rumileşme/Osmanlılaşma ile bu gecikmiş Osmanlılaşma arasındaki ilişsi aydınlatılmaya muhtaçtır. ${ }^{79}$ Sanat alanındaki değişimlere Cem Behar ve Tülay Artan'ın bahsi geçen yaklaşımlarını alıntılarla veren Baki Tezcan'ın ise bu dönem için seçtiği başlık "II. Osmanlı İmparatorluğu"dur. ${ }^{80}$ Feldman da, çok önce dikkat çektiği bu on altıncı yüzyıl sonu ile başlayan yeni döneme (1580-1830) "Osmanlı Orta Dönemi” (Ottoman Middle Period) adını vermiştir. ${ }^{81}$

On yedinci yüzyıl ile birlikte imparatorluğun kültürel ortamında da yeni bir döneme girildiği birçok araştırma ile vurgulansa dahi bu yeni dönem henüz sağlam bir zemin bulabilmiş değildir. ${ }^{82}$ Artan mecmua yazımı, kitap okuma oranlarının artışı, elit bir zümrenin doğması ve gelişmesi, "çelebiler çağı," ${ }^{83}$ Kadızâdeli hareketinin sonlanması, yeni kamusal alanların ortaya çıkışı ve gelişen/genişleyen müzik hamiliği modeli ile modern Osmanlı toplumunun bir pozitifi çıkmaktadır. Feldman'ın ilk üç dönem için değindiği sophistication (entelektüelleşme) tam da bu çerçevede ele alındığında daha ikna edici bir hal almaktadır. ${ }^{84}$ Öte yandan Panofsky’nin, skolastik metinler ile Gotik mimarlık arasında kurduğu benzerliğin bu konuda da ilham verici olduğu kanaatindeyim. Panofsky, manifestatio (açıklık ilkesi) doğrultusunda, skolastik metinlerin yeni bilgiyi tasnif çabasıyla gelişen kurgusu ile Gotik mimarlığın
Tablo 4: Üç farkı disiplinde yaygınlık kazanan dönemlendirme yaklaşımları

77 Tülay Artan, "Arts and Architecture," The Later Ottoman Empire, 1603-1839. The Cambridge History of Turkey, c. 3, der. Suraiya N. Faroqhi (Cambridge: Cambridge University Press, 2006), 415-419.

78 Behar, Osmanl/Türk Musıkisinin Kısa Tarihi, 17.

79 Nuran Tezcan, "Sebeb-i Teliflere Göre Mesnevi Edebiyatının Tarihsel Dönüusümü," Doğu Batı 13, s. 52 (Şubat-Mart-Nisan 2010): 49-75. 80 Baki Tezcan, Second Ottoman Empire: Political and Social Transformation in the Early Modern World (Cambridge: Cambridge University Press, 2012).

81 Feldman, Music of the Ottoman Court, 59 .

82 Düşünce tarihi çalışmalarında da bu dönemde bir değişimin varlığından bahsedilmektedir. Bkz. ibrahim Halil Üçer, "ỉslam Düşünce Tarihi için Bir Dönemlendirme Önerisi," ILEM 2017-2018 Açıllş Konferansı (istanbul: ILEMM, 2017), 17.

83 Cemal Kafadar, "17. yüzyll Çelebiler Çă̆ı," Medyascope Kültür ve Tarih Sohbetleri 57, erişim tarihi 18 Kasım 2019, https://medyascope. tv/2017/06/20/kultur-ve-tarih-sohbetleri-57-cemal-kafadar-ile-17-yuzyil-celebiler-cagi/.

84 On yedinci yüzyılda edebiyat dünyasındaki değişimlere bakıldığında da aynı ana tema görülür. Mehmet Kalpaklı bu değişimden şöyle bahseder: "Türk şiirinin artık İran şiiri etkisinden tamamen kurtulduğu on yedinci yüzyllın başlarında Kadızâdeliler'in bertaraf edilmesi ve kültürde ve edebiyatta baskının ortadan kalkmasılla, öznellik, yerellik, orijinallik, gündelik konular, temsilî konular, yani daha alegorik konular edebiyata girmeye başladı. Böylece, Itrî̀nin yaşadığı dönem Osmanlı kültürü ve edebiyatı için bir yeniden açılma, arayış ve ilerleme devri oldu." Bkz. Mehmet Kalpaklı, "Itrî Döneminde Osmanlı'da Şiir," Itrî ve Dönemine Disiplinlerarası Baklşlar, der. Emre Ayvaz ve Illkay Baliç (İstanbul: İstanbul Kültür ve Sanat Vakfi, 2013), 21. 
yapısal unsurları arasında belli paralellikler olduğunu öne sürmüştür. ${ }^{85}$ Aynı benzerlik, peşrev formunun değişimi, faslın ortaya çıkışı ile mecmua ve edvârların yapısal değişimi arasında kurulabilir mi? Böyle bir benzerliğin tespiti paralel okumalara kaynak sağlayacaktır. Özellikle peşrev formunun, zamanla hanelerin belli bir eşitlik düzleminde modern yapısını kazandığı, gelişim çizgisi veya başı sonu belli bir "fasıl” anlayışının ortaya çıkması ile on yedinci yüzyılda özellikle artan bilgi-enformasyonla beraber mecmua ve edvârların değişen iç kurgusu bu okumalara yön kazandıracak niteliktedir.

Bir başka problem ise gerek kurucu unsur olarak gerekse de on altıncı ve on yedinci yüzyılın ilk yarısı için söz konusu olan 'Acem etkisi' üzerinde yeterince durulmamasıdır. Cumhuriyetin kuruluş döneminde gelişen ulusalcılık eksenli yaklaşımların halen dönem tasvirlerimiz üzerinde etkin olduğunu söylemek gerekir. Çoğunlukla padişahların İran'dan davet ettikleri müzisyenlere indirgenen ve sarayla sinırlı kaldığı varsayılan bu Acem etkisinin yeniden ele alınması gerekir. ${ }^{86}$ İran coğrafyasından gelen şair ve âlimlerin büyük bir ilgi gördüğ̈ bir kültürel ortamda Acem müzisyenleri bunun dışında bırakmak çok yerinde olmayacaktır. Müte’accim gibi bir kavramın gelişmesine imkân sağlayan Anadolu coğrafyasına hâkim Acem kültürleşmesi, müzik ekseninde tekrar ele alınmalıdır. ${ }^{87} \mathrm{On}$ altıncı ve on yedinci yüzyılın ilk yarısında Acem etkisine bağlı olarak yayıldığı varsayılan çok fazla tekrar eden melodik yapılardan oluşan beste anlayışı bu anlamda ilk tartışma konusu olarak karşımıza çıkmaktadır. ${ }^{88}$

On sekizinci yüzyıla gelindiğinde artık kendini açık bir şekilde gösteren Osmanlı kent nüfusunun kamusal alanda hızla artan görünürlüğü ve buna paralel bir çeşit zenginlik, mevki ve statü göstergesi olarak müziğin de araçsallaşması, gelişen yeni hamilik modelleri, en başta müziği saraya sıkıştıran kabulleri revize etmemizi zorunlu kılıyor. ${ }^{89}$ Hiç şüphesiz saray ve köşklerin yanında popülerleşen meyhane, kahvehane ve mesirelerdeki icra üslubu birbirlerinden oldukça farklı olmalıydı. Shirine Hamadeh'in on sekizinci yüzyılın mimari üretimi üzerine yaptığı ve edebi kaynaklarla genişlettiği ufuk açıcı değerlendirmesi Şehr-i Safa: 18. Yüzyılda İstanbul, bu bağlamda müzik üretimi ile paralel olarak da ele alınmaya muhtaç. Hamadeh'in décloisonnement (açılma) olarak adlandırdığı, hayli melez ve oldukça yenilikçi olarak tanımladığı on sekizinci yüzyılda değişen toplumsal ve kültürel ortam fikri ile niceliksel müzik üretiminin bir paralellik ifade ettiği söylenebilir. Ancak Hamadeh'in mimari eserler üzerindeki analizler yerine toplumsal pratiklerin değişimi ve kamusal alanın genişlemesi üzerine temellendirdiği décloisonnement mimari kadar müzik açısından da içsel, üsluba dair bir değişimi tanımlamaz ya da bunun için daha ayrıntılı ele alınmasına ihtiyaç var. ${ }^{\circ \circ}$

Sonuç olarak Osmanlı-Türk müziği tarihyazımında yeni bir değerlendirmenin ihtiyacı ve geçiş, dönüşüm, inkıta mefhumları üzerine yoğunlaşılması gerekliliği açıkça görülmektedir. Tarihyazımında süregelen klasik dönem, altın çağ, on yedinci yüzyıl krizi, gerileme, erken modern, modern, II. İmparatorluk gibi dönem tartışmalarına müzik camiasının da bir an evvel dâhil olması gerekir. Şeyhülislam Esad Efendi, Kantemiroğlu ve Hızır Ağa’nın dâhil olduğu on yedinci yüzyıldan on sekizinci yüzylla kadar sarkan "Eskiler" (mütekaddimîn) ve "Yeniler" ayrımı, ${ }^{91}$ on beş ve on altıncı yüzyıllar arasındaki karanlık zaman dilimi, ${ }^{92}$ erken dönem yazılı kaynakları ile on dokuzuncu yüzyıl arasındaki üslup farklılıkları, on sekizinci yüzyılda yaşandığı düşünülen değişim, yirminci yüzyıldaki geçiş/değişim, müzik alanının dönemlendirme ile ilgili başlıca tartışma başlıklarıdır. Bu başlıkların her biri ayrı ayrı ele

85 Erwin Panofsky, Gotik Mimarlk ve Skolastik Felsefe, Ortaçağda Sanat, Felsefe ve Din Arasindaki Benzerliklerin İncelenmesi, çev. Engin Akyürek (İstanbul: Kabalcı Yayınevi, 2014).

86 İsmail Hakkı Uzunçarşıl1, "Osmanlılar Zamanında Saraylarda Musiki Hayatı," Belleten 41 (1977): 79-114.

87 Cemal Kafadar, Kendine Ait Bir Roma: Diyar-ı Rum'da Kültürel Coğrafya ve Kimlik Üzerine (ìstanbul: Metis Yayınları, 2017), 41. Tıpkı "gerileme/inhitat" tartışmasında olduğu gibi bu Acem etkisi son çalışmalarda yüksek sesle dillendirilir olsa dahi henüz adı konamamıştır. Bu konuda birçok ufuk açıcı çalışmaya ek olarak Barış Ünlü'nün Osmanlı'nın soykütüğü minvalinde kuruluş dönemine odaklandığı çalıșması tartışmaları teorik bir düzlemde ele alıyor. Ünlünün Braudel ve ỉbn Halduncu bir perspektifle ele aldığı Osmanlı tarihyazımı, Osmanl1-Türk kültürü ve müziği çalışmaları için tartışılmaya değer çok kıymetli konu ve teorik çerçeveler sunuyor. Özellikle köken tartışmaları için Ünlü’nün yaklaşımı müzik ekseninde yeniden yorumlanmalı. Bkz. Barış Ünlü, Osmanll: Bir Dünya-Imparatorluğu Soykütüğ̈̈ (İstanbul: Dipnot Yayınları, 2016).

88 Feldman'ın Kantemir edvarındaki eserlerin segâh sesi için çağdaş İran müziği ile kurduğu benzerlik, daha da ileri götürülerek üslup boyutunda da kurulabilir. Böyle bir yaklaşımın adımlanı için bkz. Ârash Mohâfez, Ajamlar: Compositions Attributed to Iranian Musicians in Ali Ufki \& Dimitrie Cantemir's Collections (Tahran: Mahoor Institute, 2015).

89 Selman Benlioğlu, Saray ve Musiki, III. Selim ve II. Mahmud Dönemlerinde Musikinin Himayesi (ìstanbul: Dergah Yayınları, 2018).

9o Hamadeh, Şehr-i Safa; "Westernization, Decadence, and the Turkish Baroque: Modern Constructions of the Eighteenth Century,"

Muqarnas 24 (2007): 185-197.

91 Behar, Şeyhülislâmın Müziği, 61-73.

92 Feldman, Music of the Ottoman Court, 45. 
160 alınmalıdır. Bu aşamada müzik tarihi ve müzikoloji çalışmalarının yanı sıra kültür tarihi çalışmalarının, üslup ve form analizleri ile desteklendiği bir Osmanlı-Türk müziği tarihyazımı en ideal yol olarak görülmektedir. Üsluba dair hiçbir yorum taşımayan dönem tasvirleri müzik adına temelsiz kalmaya mahkûmdur. Giriş bölümünde aktarıldığı gibi bu dönemlerin tarihyazım karakteri doğrultusunda üslubunun tasvirine yönelik veya üslubundan tarihyazımına yönelik hayali adımlar atmaktan çekinilmemelidir. Bir şekilde temellendirilebilen bu hayali adımlar alanın genişlemesinde en kritik rolü üstlenecektir. Sosyal bilimler bu anlamda adımların üzerinde atılabileceği birçok teorik çerçeve sunmaktadır. Örneğin, Hegelci ilerleme teorisinin sağladığı imkânlar bir tarafa-kültür-sanat tarihi yazımındaBourdieucü kültürel miras kavramı da teorik olarak mümbit bir yaklaşım önermektedir. ${ }^{93}$

Tüm bu dönemlendirme çabalarının müzik alanındaki başarısını ise Avrupa'da yirminci yüzyıl sonlarına doğru ortaya çıkan historically informed performance (HIP) ${ }^{94}$ (dönemsel icra) çalışmalarının niceliği ve nitelikleri ile değerlendirmek mümkündür. Erken dönem kilise müziği (Gregorian Chant, ${ }^{95}$ Ambrosian Chant), Rönesans, Barok vb. dönem müzikleri üzerine büyük çoğunluğu 1990'larda yapılan albüm çalışmalarının çoğu bu tartışmaların ürünüdür. Müzikolog-icracıların ${ }^{96}$ başını çektiği bu girişimler belli bir dönem üzerinde dönem sazlarından, icra üslubuna, sosyal ortamından repertuvarına kadar geniş bir alan üzerinde çalışmaktadır. Dönemlendirme çalışmalarının sunduğu malzemeyi performansa dönüştürmeyi amaçlayan dönemsel icra ile ilgili çalışmaların Osmanlı-Türk müziğindeki tek örneğini ise Fikret Karakaya yönetimindeki Bezmârâ Topluluğu vermiştir. ${ }^{97}$ Teorik çalışmalara farklı bir perspektif kazandıran benzeri girişimler, üslupla ilgili tartışmalar için ciddi önem taşımaktadır. Tarihsel müzikoloji alanı için nihai bir sonucu vaat eden dönemsel icra mefhumu ve ona eklemlenen dönemlendirme çalışmaları, Osmanlı-Türk müziği için eski bir tartışmayı yeniden ele almayı öneriyor.

93 Pierre Bourdieu ve Jean Claude Passeron, Varisler: Öğrenciler ve Kültür, çev. Levent Ünsaldı and Aslı Sümer (İstanbul: Heretik Yayıncılık, 2014); Pierre Bourdieu, The Field of Cultural Production, haz. Randal Johnson (New York: Columbia University Press, 1993).

94 Historically informed performance (dönemsel icra) literatürüne dikkatimi çeken Alper Maral'a teşekkür ederim. Bu konudaki yaklaşım ve tartışmalar için bkz. Richard Taruskin, Text and Act (Oxford: Oxford University Press, 1995); Daniel Leech-Wilkinson, The Modern Invention of Medieval Music Scholarship, Ideology, Performance (Cambridge: Cambridge University Press, 2002); John Butt, Playing With History; The Historical Approach to Musical Performance (Cambridge: Cambridge University Press, 2002).

95 Peter Jeffrey, Re-Envisioning Past Musical Cultures: Ethnomusicology in the Study of Gregorian Chant (Chicago: University of Chicago Press, 1992).

96 Müzik teorisi ile uğraşan her bireyden amatör düzeyde de olsa bir saz icra etmesi eğitim sürecinde dahi beklense de, müzikolog-icrac1 ile kastedilen müzik tarihi ve teori ile desteklenmiş icra önerisi getirebilecek bir müzisyen profili Osmanlı-Türk müziğine tamamen yabancidır.

97 Bezmârâ Topluluğu, 1996 yılında, erken dönem Osmanlı-Türk müziği icra etmek üzere kurulmuş bir gruptur. Özellikle on yedinci yüzyıldan günümüze ulaşabilen eserleri yine dönemin bugün unutulmus sazlarıyla icra etmektedir. Karakaya'nın dönemsel icra literatürü ve tartışmalarına dâhil olmadan sunduğu konu ile ilgili genel yaklaşımı için bkz. Fikret Karakaya, "Do Early Notation Collections Represent the Music of their Times?," Writing the History of "Ottoman Music, 213-217. 


\section{Yayımlanmış Birincil Kaynaklar}

Ali Ufkî. Mecmua-i Saz ü Söz. Hazırlayan Şükrü Elçin. Ankara: T.C. Kültür Bakanlığı, 2000.

Dimitri Kantemir, Kantemiroğlu; Kitabu "İlmi"l Mûsikî "âlâ Vechi"l-Hurufât - Musikîyi Harflerle Tespit ve İcrâ Ilminin Kitabı. Cilt 1. Hazırlayan Yalçın Tura. İstanbul: Yapı Kredi Yayınları, 2001.

—. Osmanl Imparatorluğu’nun Yükseliş ve Çöküş Tarihi. Çeviren Özdemir Çobanoğlu. İstanbul: Cumhuriyet Kitapları, 1998.

Launay, Victor-Marie de et al. Osmanlı Mimarisi: Usul-i Mi’mari-i Osmani. Hazırlayan Raşit Gündoğdu, Illhan Ovalığlu, Ebul Faruk Önal ve Cevat Ekici. İstanbul: Çamlıca Yayınevi, 2011.

\section{ikincil Kaynaklar}

Armağan, Mustafa, der. Osmanl Tarihini Yeniden Yazmak: Gerileme Paradigmasının Sonu. İstanbul: Timaş Yayınları, 2011.

Arseven, Celâl Esad. Türk Sanatı. İstanbul: Cem Yayınevi, 1984.

Artan, Tülay. "Arts and Architecture." The Later Ottoman Empire, 1603-1839. The Cambridge History of Turkey, cilt 3, derleyen Suraiya N. Faroqhi, 415-419. Cambridge: Cambridge University Press, 2006.

Ayangil, Ruhi. "Thoughts and Suggestions on Writing Turkish Music History." Writing the History of "Ottoman Music," derleyen Martin Greve, çeviren Efkan Uğuz, Martin Greve ve Onur Nobrega, 51-56. Würzburg: Ergon-Verlag, 2015.

Başer, Fatma Adile. Türk Mûsikîsinde Abdülbâkî Nâsır Dede: Abdülbaki Dedénin Hayatı ve "Tedkîk u Tahkîk." İstanbul: Fatih Üniversitesi Yayınları, 2013.

Behar, Cem. Aşk Olmayınca Meşk Olmaz: Geleneksel Osmanlı/Türk Musıkisinde Öğretim ve İntikal. İstanbul: Yapı Kredi Yayınları, 2016.

—. Osmanl//Türk Musıkisinin Kısa Tarihi. İstanbul: Yapı Kredi Yayınları, 2015.

-. Saklı Mecmua: Ali Ufkînin Bibliotheque Nationale de France'daki [Turc 292] Yazmast. İstanbul: Yap1 Kredi Yayınları, 2008.

—. Şeyhülislâmın Müziği: 18. Yüzyllda Osmanl/Türk müziği ve Şeyhülislâm Es’ad Efendi’nin Atrâbü’l Âsârı. İstanbul: Yapı Kredi Yayınları, 2010.

—. Musikiden Müziğe, Osmanll/Türk Müziği: Gelenek ve Modernlik. İstanbul: Yapı Kredi Yayınları, 2005.

Benlioğlu, Selman. Saray ve Musiki, III. Selim ve II. Mahmud Dönemlerinde Musikinin Himayesi. İstanbul: Dergah Yayınları, 2018.

Berker, Ercümend. “Türk Musikisinde Dönemler.” Erdem Dergisi 1, s. 1 (1985): 147-168.

Bourdieu, Pierre. The Field of Cultural Production. Hazırlayan Randal Johnson. New York: Columbia University Press, 1993.

Bourdieu, Pierre, ve Jean Claude Passeron. Varisler: Öğrenciler ve Kültür. Çeviren Levent Ünsaldı ve Aslı Sümer. İstanbul: Heretik Yayıncıllk, 2014.

Bozkurt, Barış, Ruhi Ayangil, ve André Holzapfel. "Computational Analysis of Turkish Makam Music: Review of State-of-the-Art and Challenges." Journal of New Music Research 43, s. 1 (Ocak 2014): 3-23.

Braudel, Fernand. Maddi Uygarlı: Dünyanın Zamanı. Çeviren Mehmet Ali Kılıçbay. İstanbul: İmge Kitabevi, 2004.

—. Tarih Üzerine Yazılar. Çeviren Mehmet Ali Kılıçbay. İstanbul: Doğu Batı Yayınları, 2016.

Butt, John. Playing with History, The Historical Approach to Musical Performance. Cambridge: Cambridge University Press, 2004.

Carrier, David. A World Art History And Its Objects. University Park: Pennsylvania State University Press, 2008.

Cevher, M. Hakan. “Ali Ufki ve Haza Mecmua-i Saz ü Söz. Transkripsiyon ve İnceleme.” Doktora tezi, Ege Üniversitesi, 1995 .

Darling, Linda T. "Another Look at Periodization in Ottoman History." The Turkish Studies Association 26, s. 2 (2015): 19-28.

Doğrusöz, Nilgün. "Hafız Post Güfte Mecmuası (Türkçe Güfteler).” Yüksek lisans tezi, İstanbul Teknik Üniversitesi, 1993.

—. "History of Ottoman/Turkish Music Theory." Writing the History of "Ottoman Music," derleyen Martin Greve, çeviren Efkan Uğuz, Martin Greve ve Onur Nobrega, 77-86. Würzburg: ErgonVerlag, 2015 .

—_. "Nâyî Osman Dede’nin Müzik Yazısına Dair Birkaç Belge," Musıkişinas 8 (2006): 47-66.

Eco, Umberto. Açık Yapıt. Çeviren Yakup Şahan. İstanbul: Kabalcı Yayıncılık, 1992.

Ekinci, Mehmet Uğur. Kevseri Mecmuası: 18. Yüzyıl Saz Müziği Külliyatı. İstanbul: Pan Yayıncılık, 2016. 

Music." Journal of the Royal Asiatic Society 22, s. 2 (2012): 199-225.

—_. "Kantemiroğlu Notalarının Bilinmeyen Bir Nüshası." Musikişinas 13 (2015): 75-125

Erimtan, Can. "The Sources of Ahmed Refik's Lâle Devri and the Paradigm of the 'Tulip Age': A Teleological Agenda." Essays in Honour of Ekmeleddin Ihsanoğlu, derleyen Mustafa Kaçar ve Zeynep Durukan. İstanbul: IRCICA, 2006.

Ersoy, Ahmet. "On the Sources of the 'Ottoman Renaissance': Architectural Revival and its Discourse During the Abdülaziz Era (1861-1876)." Doktora tezi, Harvard University, 2000.

Febvre, Lucien. Rönesans Insant. Çeviren Mehmet Ali Kılıçbay. İstanbul: İmge Kitabevi, 1995.

Feldman, Walter. Music of Ottoman Court: Makam, Composition and the Early Ottoman Instrumental Repertoire. Berlin: VWB-Verlag für Wissenschaft und Bildung, 1996.

—. "The Musical 'Renaissance' of Late Seventeenth Century Ottoman Turkey: Reflections on the Musical Materials of Ali Ufkî Bey (ca. 1610-1675), Hâfız Post (d.1694) and the 'Marâghî' Repertoire." Writing the History of "Ottoman Music," derleyen Martin Greve, çeviren Efkan Uğuz, Martin Greve ve Onur Nobrega, 87-138. Würzburg: Ergon-Verlag, 2015, 87-138.

Gerhard, Dietrich. "Periodization in European History." The American Historical Review 61, s. 4 (1956): 900-913.

Godt, Irving. "Style Periods of Music History Considered Analytically." College Music Symposium 24, s. $1(1984): 33-48$.

Gulbenkian Komisyonu. Gulbenkian Komisyonu Sosyal Bilimleri Açın. Çeviren Şirin Tekeli. İstanbul: Metis Yayınları, 2016.

Halkin, Léon-E. Tarih Tenkidinin Unsurları. Çeviren Bahaeddin Yediyıldız. Ankara: Türk Tarih Kurumu Yayınlar1, 1989.

Hamadeh, Shirine. Şehr-i Safa: 18. Yüzyılda İstanbul. Çeviren ilknur Güzel. İstanbul: İletişim Yayıncılık, 2010.

—. "Westernization, Decadence, and the Turkish Baroque: Modern Constructions of the Eighteenth Century." Muqarnas 24 (2007): 185-197.

Harris, Olivia. "Braudel: Historical Time and the Horror of Discontinuity." History Workshop Journal 57 (Bahar 2004): 161-174.

Haug, Judith I. Ottoman and European Music in 'Alī Ufukị̂s Compendium, MS Turc 292: Analysis, Interpretation, Cultural Context. Münster: WWU Münster, 2019.

Iggers, Georg G. Bilimsel Nesnellikten Postmodernizme Yirminci Yüyzyılda Tarihyazımı. Çeviren Gül Çă̆alı Güven. İstanbul: Tarih Vakfı Yurt Yayınları, 2016.

İnalcık, Halil. "Adâletnâmeler." Türk Tarih Kurumu Belgeler 2, s. 3-4 (1965): 49-142.

- Essays in Ottoman History. İstanbul: Eren Yayinc1lik, 1998.

Jeffrey, Peter. Re-Envisioning Past Musical Cultures: Ethnomusicology in the Study of Gregorian Chant. Chicago: University of Chicago Press, 1992.

Jameson, Fredric. A Singular Modernity: Essay on the Ontology of the Present. Londra: Verso Books, 2002. Jordheim, Helge. "Against Periodization: Koselleck's Theory of Multiple Temporalities." History and Theory 51, s. 2 (2012): 151-171.

Kafadar, Cemal. Kendine Ait Bir Roma: Diyar-ı Rum'da Kültürel Coğrafya ve Kimlik Üzerine. İstanbul: Metis Yayınları, 2017.

Kafadar, Cemal. "The Myth of Golden Age: Ottoman Historical Conciousness in the Post Süleymânic Era." Süleymân the Second and His Time, derleyen Halil İnalcık ve Cemal Kafadar, 1-19. İstanbul: The Isis Press, 1993.

Kalpaklı, Mehmet. "Itrî Döneminde Osmanlı'da Şiir." Itrî ve Dönemine Disiplinlerarası Bakışlar, derleyen Emre Ayvaz ve İlkay Baliç, 19-22. İstanbul: İstanbul Kültür ve Sanat Vakfı, 2013.

Karadeniz, Şirin. “Türk Müziğinde Dönem Anlayışı.” Yüksek lisans tezi, İstanbul Teknik Üniversitesi, 2007.

Karakaya, Fikret. "Do Early Notation Collections Represent the Music of their Times?" Writing the History of "Ottoman Music," derleyen Martin Greve, çeviren Efkan Uğuz, Martin Greve ve Onur Nobrega, 213-17. Würzburg: Ergon-Verlag, 2015.

Karaosmanoğlu, M. Kemal. "A Turkish Makam Music Symbolic Database for Music Information Retrieval: SymbTr.” Proceedings of ISMIR 2012. Erişim tarihi 17 Kasım 2019. https://ismir2012.ismir.net/event/papers/223_ISMIR_2012.pdf.

Karateke, Hakan T. "The Challenge of Periodization: New Patterns in Nineteenth-Century Ottoman Historiography." Writing History at the Ottoman Court, derleyen Erdem Ç1pa ve Emine Fetvac1, 129154. Bloomington: Indiana University Press, 2013.

Kelley, Donald R. "Periodization." New Dictionary of the History of Ideas, derleyen Maryanne Cline Horowitz, 1730-32. Michigan: Thomson Gale, 2005. 
Korkmaz, Harun. The Catalog of Music Manuscripts in Istanbul University Library. Cambridge: Harvard University Press, 2015.

Koselleck, Reinhart. Kavramlar Tarihi: Politik ve Sosyal Dilin Semantiği ve Pragmatiği Üzerine Araştırmalar. Hazırlayan Tanıl Bora, çeviren Atilla Dirim. İstanbul: İletişim Yayınları, 2006.

. The Practice of Conceptual History: Timing History, Spacing Concepts. Çeviren Todd Presner et al. Stanford: Stanford University Press, 2002.

Kubler, George. The Shape of Time: Remarks on the History of Things. New Haven: Yale University Press, 2008.

Kuban, Doğan. Türk Barok Mimarisi Hakkında Bir Deneme. İstanbul: Pulhan Matbaası, 1954.

Kyriakos Kalaitzides. Post-Byzantine Music Manuscripts as a Source for Oriental Secular Music (15th to Early 19th Century). Çeviren Dimitri Koubaroulis. Würzburg: Ergon-Verlag, 2012.

Le Goff, Jacques. Must We Divide History Into Periods? Çeviren M.B. DeBevoise. New York: Columbia University Press, 2015.

Leech-Wilkinson, Daniel. The Modern Invention of Medieval Music Scholarship, Ideology, Performance. Cambridge: Cambridge University Press, 2002.

Lowry, Heath W. Defterology Revisited: Studies on $15^{\text {th }}$ and $16^{\text {th }}$ Century Ottoman Society. İstanbul: The ISIS Press, 2008.

Mohâfez, Ârash. Ajamlar: Compositions Attributed to Iranian Musicians in Ali Ufki \& Dimitrie Cantemir's Collections. Tahran: Mahoor Institute, 2015.

Nasır Abdülbâki Dede. Tedkîk ü Tahkîk. Hazırlayan Yalçın Tura. İstanbul: Pan Yayıncılık, 2006.

Necipoğlu, Gülru. "Creation of a National Genius: Sinan and the Historiography of 'Classical' Ottoman Architecture." Muqarnas 24 (2007): 141-183.

Nelson, Robert S. "The Map of Art History." The Art Bulletin 79, s. 1 (1997): 28-40.

Olley, Jacob. "Modal Diversity in Early Ottoman Music: The Case of Makâm Sabâ." NEMO-Online 1, s. 1 (2012): 35-50.

Özcan, Abdülkadir. "Lâle Devri.” İslam Ansiklopedisi. Erişim tarihi 17 Kasım 2019. https://islamansiklopedisi.org.tr/lale-devri\#1.

Özel, Oktay. Dün Sancısı, Türkiye'de Geçmiş Algısı ve Akademik Tarihçilik. İstanbul: Kitabevi Yayınevi, 2009.

Özvar, Erol. “Osmanlı Tarihini Dönemlendirme ve Nasihat Literatürü.” Divan 2 (1999): 135-51.

Panofsky, Erwin. Gotik Mimarlık ve Skolastik Felsefe: Ortaçağda Sanat, Felsefe ve Din Arasındaki Benzerliklerin Incelenmesi. Çeviren Engin Akyürek. İstanbul: Kabalcı Yayıncılık, 2014.

Popescu-Judetz, Eugenia. Kevseri Mecmuası. Çeviren Bülent Aksoy. İstanbul: Pan Yayıncılık, 1998.

—. Tanburi Küçük Artin: A Musical Treatise of the Eighteenth Century. İstanbul: Pan Yayıncılık, 2002.

Preziosi, Donald. The Art of Art History: A Critical Anthology. Oxford: Oxford University Press, 2009.

Şakul, Kahraman. "Bir Çalıştayın Ardından. 17. Yüzyılda Osmanlı İmparatorluğu: Kriz ve Dönüşüm.” Toplumsal Tarih 223 (2012): 22-38.

Tanju, Bülent, der., Tereddüd ve Tekerrür: Mimarlı ve Kent Üzerine Metinler: 1873-1960. İstanbul: Metis Yayınları, 2007.

Taruskin, Richard. Text and Act. Oxford: Oxford University Press, 1995.

Tekin, Abdülkadir. Türk Musikisinde Nağmeler ve Makamlar; Kemânî Hızır Ağa’nın Tefhimül Makâmât fî Tevlîdi’n Nagâmât İsimli Edvâr’’ Örneğinde 18.Yüzyıl Türk Mûsikîsi. İstanbul: Büyüyenay Yayınları, 2015 .

Tezcan, Baki. Second Ottoman Empire : Political and Social Transformation in the Early Modern World. Cambridge: Cambridge University Press, 2012.

Tezcan, Nuran. "Sebeb-i Teliflere Göre Mesnevi Edebiyatının Tarihsel Dönüşümü,” Doğu Batı 13, s. 52 (Şubat-Mart-Nisan 2010): 49-75.

Tura, Yalçın. Türk Musikisinin Meseleleri. İstanbul: Pan Yayıncılık, 1998.

Unamuno, Miguel de. Sis. İstanbul: İş Bankası Kültür Yayınları, 2016.

Uslu, Recep. “Türk Müziği Tarihinde Yeni Bir Dönemlendirme Önerisi.” Medeniyet Sanat 1, s. 2 (2015): 91-109.

Uyar, Burak, Hasan Sercan Atli, Sertan Şentürk, Barış Bozkurt, ve Xavier Serra. "A Corpus for Computational Research of Turkish Makam Music." Proceedings of the 1st International Workshop on Digital Libraries for Musicology, yayınlayan Ben Fields, ve Kevin Page, 1-7. New York: ACM Press, 2014 .

Uzunçarşılı, İsmail Hakkı. "Osmanlılar Zamanında Saraylarda Musiki Hayatı." Belleten 41 (1977): 79-114. Üçer, İbrahim Halil. "ìslam Düşünce Tarihi İçin Bir Dönemlendirme Önerisi." ILEM 2017-2018 Açllş Konferansl, 7-39. İstanbul: ILLEM, 2017.

Ünlü, Barış. Osmanll: Bir Dünya-İmparatorluğu Soykütüğü. İstanbul: Dipnot Yayınları, 2016.

Wagner, David L. "The Middleness of the Middle Ages: Periodizing European History." Medieval Studies 
Wallerstein, Immanuel. Yeni Bir Sosyal Bilim için. İstanbul: İmge Kitabevi, 2003.

White, Hayden. Metahistory: The Historical Imagination in Nineteenth-Century Europe. Baltimore: John Hopkins University Press, 1973.

Wölfflin, Heinrich. Sanat Tarihinin Temel Kavramları. Çeviren Hayrullah Örs. İstanbul: Remzi Kitabevi, 1973.

Wright, Owen. "Aspects of Historical Change in the Turkish Classical Repertoire." Musica Asiatica 5, derleyen Richard Widdess, 1-108. Cambridge: Cambridge University Press, 1988.

_ Demetrius Cantemir: The Collection of Notations Part 1: Text. Londra: University of London, 1992. - Demetrius Cantemir: The Collection of Notations Part 2: Commentary. Farnham: Ashgate Publishing, 2000.

Words Without Songs; A Musicological Study of an Early Ottoman Anthology and its Precursors. Londra: SOAS, 1992.

Yarman, Ozan. "Makam Kuyumcuları." Saz ve Söz Internet Dergisi (Nisan 2019). Erişim tarihi 17 Kasım 2019. www.ozanyarman.com/files/kuyumcular.pdf.

Yekta, Rauf. "Ziya Gökalp Bey ve Millî Musikimiz Hakkındaki Fikirleri (I).” Musiki Mecmuast 458 (1997 [1925]): 5-7. 